\title{
Constitution of Four New Hasubanan Alkaloids from Stephania japonica Mrers ${ }^{1)}$
}

\author{
Matao Matsui, Yasuo Watanabe, ${ }^{2 a}$ ) Toshiro Ibuka \\ and KIYOSHI TANAKA $^{2 b)}$
}

\begin{abstract}
Daiichi College of Pharmaceutical Sciences ${ }^{\left.2 a_{n}\right)}$ and Faculty of Pharmaceutical Sciences, Kyoto University ${ }^{2 b)}$
\end{abstract}

(Received November 22, 1974)

\begin{abstract}
Four new hasubanan alkaloids, stephamiersine (1), epistephamiersine (2), oxostephamiersine (3) and stephasunoline (4) were isolated together with seven known and three unidentified alkaloids from Stephania japonica Miers (Menispermaceae). Among these new alkaloids, 1 and 2 were found to be epimeric isomers with respect to the C-7 methoxyl group. . Permanganate oxidation of 1 gave 3 , and borohydride reduction of 1 and 2 gave the highly stereoselective products, dihydrostephamiersine (6) and dihydroepistephamiersine (5). On mild treatment of 5 with hydrochloric acid gave 4 . Acetolyses of $1,2,5$ and 6 gave the phenanthrene derivatives, $\mathbf{7 , 8}$ and $\mathbf{9}$, respectively. Further, both 1 and 2 were converted to the conjugated carbonyl compound (14) which was obtained from dihydro16-oxohasubanonine (17a) (17b). On the other hand, the stereochemistry of $1,2,3$ and 4 was elucidated by nuclear magnetic resonance (NMR) spectroscopic studies as follows: the C-7 methoxyl group of 1 has the $\alpha$-axial and that of 2 and 4 has the $\beta$-equatorial configuration, and the hydroxyl group of 4 has the $\beta$-axial one. On the basis of the above chemical correlation coupled with the spectral arguments, the constitution of the new alkaloids was represented as drawn in the formulas, 1, 2, 3 and 4.
\end{abstract}

In the course of an investigation on the non-quaternary bases of Stephania japonica Mrers (Menispermaceae) collected in Kagoshima Prefecture, we have recently isolated four new hasubanan alkaloids, named stephamiersine (1), epistephamiersine (2), oxostephamiersine (3) and stephasunoline (4) together with seven known and three unidentified bases. The present paper deals with the elucidation of structure and absolute stereochemistry of the new alkaloids.

The methanolic extract prepared from the stems and rhizomes of Stephania japonica MIERs, as described in the experimental section, was digested with dilute aqueous citric acid, then the acid solution was shaken with chloroform to separate the chloroform layer ("weak base fraction") and the acid layer ("strong base fraction"). Each fraction was worked up by the usual method and the "weak base fraction" gave stephamiersine (1), epistephamiersine (2), oxostephamiersine (3), metaphanine, ${ }^{3)}$ stephanine $^{4}$ ) and unidentified bases, tentatively named base- $\mathrm{X}$, base-S and base-P (non-phenolic), and hypoepistephanine ${ }^{5)}$ (phenolic). The

1) Preliminary communication of this work appeared in Tetrahedron Letters, 1973, 4263. This paper forms Part CCLXIII of the series "Studies on the Alkaloids of Menispermaceous Plants." Part CCLXII: J. Kunitomo, Y. Hasegawa, Y. Imori and E. Yuge, Yakugaku Zasshi, 92, 1496 (1972).

2) Location: a) 93 Tamagawa-cho, Minami-ku, Fukuoka, 815, Japan; b) Yoshida-shimoadachi-cho, Sakyo-ku, Kyoto, 606, Japan.

3) a) H. Kondo and T. Sanada, Yakugaku Zasshi, 45, 5, 1039 (1924); idem, ibid., 48, 177, 930 (1927); H. Kondo and T. Watanabe, ibid., 58, $268(1938)$; b) M. Tomita, T. Ibuka, Y. Inubushi and K. Takeda, Tetrahedron Letters, 1964, 3605; idem, Chem. Pharm. Bull. (Tokyo), 13, 695, 704 (1965).

4) M. Tomita and H. Shirai, Yakugaku Zasshi, 62, 381 (1942); H. Shirai, ibid., 64B, 208 (1944); H. Shirai and N. Oda, ibid., 76, 1287 (1956).

5) H. Kondo and T. Nozoe, Yakugaku Zasshi, 63, 333 (1943); M. Tomita and E. Fujita, Chem. Pharm. Bull. (Tokyo), 2, 378 (1954).

6) H. Kondo and T. Sanada, Yakugaku Zasshi, 514, 1039 (1924); idem, ibid., 541, 177 (1927); idem, ibid., 549, 930 (1927); H. Kondo and K. Tanaka, ibid., 63, 267, 273 (1943); K. Tanaka, ibid., 64, 28 (1944). 
"strong base fraction" gave stephasunoline (4), epistephanine, ${ }^{6)}$ protostephanine") and stebisimine $^{8)}$ (non-phenolic), hypoepistephanine and stepinonine ${ }^{9)}$ (phenolic). The phenolic base, hypoepistephanine was the only base obtainable from the both fractions. Physical constants and ultraviolet (UV), infrared (IR) and mass spectral data of the new bases, $\mathbf{1 , 2} \mathbf{2}$ and 4 thus obtained are shown in Table $I$, and nuclear magnetic resonance (NMR) spectral data are given in Table II.

TABLE I. Physical Constants and UV, IR and Mass Spectral Data of Stephamiersine (1), Epistephamiersine (2), Oxostephamiersine (3) and Stephasunoline (4)

\begin{tabular}{cccccc}
\hline $\begin{array}{c}\text { Comp. } \\
\text { No. }\end{array}$ & $\begin{array}{c}\left.\operatorname{mp}^{\circ}{ }^{\circ} \mathrm{C}\right) \\
(\text { uncorr. })\end{array}$ & $\begin{array}{c}{[\alpha] \mathrm{D}} \\
\left(\mathrm{CHCl}_{3}\right)\end{array}$ & $\begin{array}{c}\mathrm{UV} \\
\lambda_{\max }^{\mathrm{EtoH}} \mathrm{nm}(\varepsilon)\end{array}$ & $\begin{array}{c}\mathrm{IR} \\
v_{\max }^{\mathrm{CHCl}} \mathrm{cm}^{-1}\end{array}$ & $\begin{array}{c}\text { Mass Spectra }(m / e) \\
\mathrm{M}^{+} \text {and base peak }\end{array}$ \\
\hline $\mathbf{1}$ & 165 & +33.0 & $286(2200)$ & 1725 & 389,243 \\
$\mathbf{2}$ & 98 & +64.1 & $286(2300)$ & 1735 & 389,243 \\
$\mathbf{3}$ & $290,256^{a)}$ & +88.3 & $286(2000)$ & 1730,1680 & 403,257 \\
$\mathbf{4}$ & 233 & +121.4 & $286(2000)$ & 3550 & 377,245 \\
\hline
\end{tabular}

a) bimorphism

TABLE II. NMR Spectral Data ${ }^{({ })}$of Stephamiersine (1), Epistephamiersine (2), Oxostephamiersine (3), and Stephasunoline (4)

\begin{tabular}{|c|c|c|c|c|c|c|}
\hline $\begin{array}{l}\text { Compd } \\
\text { No. }\end{array}$ & Aromatic $\mathrm{H}$ & $\mathrm{C}(7)-\mathrm{H}$ & $\mathrm{C}(10)-\mathrm{H}$ & $\mathrm{OCH}_{3}$ & $\mathrm{NCH}_{3}$ & Other signals \\
\hline 1 & $6.67(2 \mathrm{H}, \mathrm{s})$ & $\begin{array}{c}3.52(1 \mathrm{H}, \mathrm{d}) \\
(J=1.5 \mathrm{~Hz})\end{array}$ & $\begin{array}{l}4.72(1 \mathrm{H}, \mathrm{d}) \\
(J=6.5 \mathrm{~Hz})\end{array}$ & $\begin{array}{l}3.92(3 \mathrm{H}, \mathrm{s}) \\
3.82(3 \mathrm{H}, \mathrm{s}) \\
3.34(3 \mathrm{H}, \mathrm{s}) \\
3.31(3 \mathrm{H}, \mathrm{s})\end{array}$ & $2.64(3 \mathrm{H}, \mathrm{s})$ & \\
\hline 2 & $6.66(2 \mathrm{H}, \mathrm{s})$ & $4.27(1 \mathrm{H}, \mathrm{s})$ & $\begin{array}{l}4.82(1 \mathrm{H}, \mathrm{d}) \\
(J=6.5 \mathrm{~Hz})\end{array}$ & $\begin{array}{l}3.89(3 \mathrm{H}, \mathrm{s}) \\
3.76(3 \mathrm{H}, \mathrm{s}) \\
3.52(3 \mathrm{H}, \mathrm{s}) \\
3.45(3 \mathrm{H}, \mathrm{s})\end{array}$ & $2.63(3 \mathrm{H}, \mathrm{s})$ & \\
\hline 3 & $6.77(2 \mathrm{H}, \mathrm{s})$ & $3.63(1 \mathrm{H}, \mathrm{s})$ & $\begin{array}{l}4.79(1 \mathrm{H}, \mathrm{d}) \\
(J=6.5 \mathrm{~Hz})\end{array}$ & $\begin{array}{l}3.92(3 \mathrm{H}, \mathrm{s}) \\
3.83(3 \mathrm{H}, \mathrm{s}) \\
3.33(3 \mathrm{H}, \mathrm{s}) \\
3.29(3 \mathrm{H}, \mathrm{s})\end{array}$ & $3.12(3 \mathrm{H}, \mathrm{s})$ & \\
\hline 4 & $6.67(2 \mathrm{H}, \mathrm{s})$ & $\begin{array}{l}3.62(1 \mathrm{H}, \mathrm{d}) \\
(J=3.9 \mathrm{~Hz})\end{array}$ & $\begin{array}{l}4.88(1 \mathrm{H}, \mathrm{d}) \\
(J=6.2 \mathrm{~Hz})\end{array}$ & $\begin{array}{l}3.90(3 \mathrm{H}, \mathrm{s}) \\
3.82(3 \mathrm{H}, \mathrm{s}) \\
3.46(3 \mathrm{H}, \mathrm{s})\end{array}$ & $2.57(3 \mathrm{H}, \mathrm{s})$ & $\begin{array}{l}4.25(1 \mathrm{H}, \mathrm{m}, \mathrm{C}(6)-\mathrm{H}) \\
4.03(1 \mathrm{H}, \mathrm{s}, \mathrm{C}(8)-\mathrm{OH}) \\
2.43(1 \mathrm{H}, \mathrm{d}, \mathrm{C}(6)-\mathrm{OH}) \\
(J=10.5 \mathrm{~Hz})\end{array}$ \\
\hline
\end{tabular}

a) All values are in $\delta$ units for $\mathrm{CDCl}_{3}$ solution at $60 \mathrm{MHz}$ with TMS as an internal standard. abbreviation: $\mathrm{s}=$ singlet, $\mathrm{d}=$ doublet, $\mathrm{m}=$ multiplet

Among the new alkaloids, 1 and $\mathbf{2}$ were found to be represented by the same formula $\left(\mathrm{C}_{21} \mathrm{H}_{27} \mathrm{O}_{6} \mathrm{~N}\right)$, and each of the IR spectra showed absorption band assignable to six-membered ketone. The above spectral data (Table I and II) suggested that $\mathbf{1}$ and $\mathbf{2}$ were closely related compounds, and this was further supported by close resemblance of fragmentation in the mass spectra. Thus, the rational formula for $\mathbf{I}$ and 2 was given as follows; $\mathrm{C}_{15} \mathrm{H}_{12} \cdot(\mathrm{C}=\mathrm{O})$. $\left(\mathrm{OCH}_{3}\right)_{4} \cdot\left(\mathrm{NCH}_{3}\right) \cdot(-\mathrm{O}-)$.

The IR spectrum of $\mathbf{3}$ showed bands at $1730 \mathrm{~cm}^{-1}$ (six-membered ketone) and $1680 \mathrm{~cm}^{-1}$ $\left(\gamma\right.$-lactam). Its NMR spectrum exhibited a signal assignable to $\mathrm{N}-\mathrm{CH}_{3}$ at lower field $(\delta 3.12)$

7) H. Kondo, T. Nakamura, M. Fujii and T. Kato, Itsuu Kenkyusho Nempo, 1, 5 (1950); H. Kondo and T. Watanabe, ibid., 1, $12(1950)$; H. Kondo and K. Tanaka, ibid., 4, $6(1953) ; 5,1(1954) ; 6,4(1955)$; 7, 30 (1956); K. Tanaka, ibid., 9, 24 (1958); H. Kondo and K. Tanaka, ibid., 9, 33 (1958).

8) D.H.R. Barton, G.W. Kirby and A. Wiechers, J. Chem. Soc. (C), 1966, 2313.

9) T. Ibuka, T. Konoshima and Y. Inubushi, Tetvahedron Letters, 1972, 4001. 
than those of $\mathbf{1}$ and $\mathbf{2}$. From these findings, $\mathbf{3}$ should be a $\gamma$-lactam, and the rational formula, $\mathrm{C}_{14} \mathrm{H}_{10} \cdot(\mathrm{C}=\mathrm{O}) \cdot\left(\mathrm{OCH}_{3}\right)_{4} \cdot\left(\mathrm{CONCH}_{3}\right) \cdot(-\mathrm{O}-)$ was given for $\mathbf{3}$.

In contrast with 1,2 and 3, the IR spectrum of $\mathbf{4}$ showed no carbonyl bands, but a sharp absorption band of hydroxyl groups at $3550 \mathrm{~cm}^{-1}$. Its NMR spectrum showed a singlet at $\delta 4.03$ due to a tertiary alcoholic proton and a doublet at $\delta 2.43(J=10.5 \mathrm{~Hz})$ ascribable to secondary alcoholic proton. These signals were disappeared by treatment with deuterium oxide. Therefore, the rational formula, $\mathrm{C}_{16} \mathrm{H}_{13} \cdot(\mathrm{OH})_{2} \cdot\left(\mathrm{OCH}_{3}\right)_{3} \cdot\left(\mathrm{NCH}_{3}\right) \cdot\left(-\mathrm{O}_{-}\right)$was presented for 4.

Mass spectral fragmentation patterns (Table III) of these bases (1, 2, 3 and 4) suggested that they were of hasubanan type ${ }^{\mathbf{1 0})}$ and most likely those bearing ketal or hemiketal moiety. Their base ion peaks well corresponded to the fragmentation which arose from loss of $\mathrm{C}$ ring from molecular ion. ${ }^{10)}$ Their closely related character was also discernible from the fragmentations.

TABLE III. Element-Table ${ }^{(\alpha)}$ of Stephamiersine (1), Epistephamiersine (2), Oxostephamiersine (3) and Stephasunoline (4)

\begin{tabular}{|c|c|c|c|c|c|c|c|}
\hline \multirow{2}{*}{$\begin{array}{c}\text { Compd. } \\
\text { No. } \\
\mathbf{1}\end{array}$} & \multirow{2}{*}{$\begin{array}{r}\begin{array}{c}\text { Relative } \\
\text { intensity }\end{array} \\
5\end{array}$} & \multirow{2}{*}{$\begin{array}{c}\begin{array}{c}m / e \\
\text { (obs.) }\end{array} \\
389.1798\end{array}$} & \multirow{2}{*}{$\frac{\begin{array}{c}\text { Error } \\
\text { (millimass unit) }\end{array}}{-3.8}$} & \multicolumn{4}{|c|}{ Elements } \\
\hline & & & & C 21 & $\mathrm{H} 27$ & $\mathrm{~N} 1$ & O6 \\
\hline & 48 & 244.1330 & -0.6 & C 15 & H 18 & $\mathrm{~N} 1$ & O 6 \\
\hline & 100 & 243.1276 & 1.7 & C 15 & H 17 & N1 & $\mathrm{O} 2$ \\
\hline & 8 & 229.1078 & -2.3 & C 14 & H 15 & N1 & $\mathrm{O} 2$ \\
\hline & 48 & 213.1123 & -2.9 & $\mathrm{C} 14$ & H 15 & N1 & 01 \\
\hline \multirow[t]{5}{*}{2} & 4 & 389.1861 & 2.4 & $\mathrm{C} 21$ & $\mathrm{H} 27$ & N1 & 06 \\
\hline & 44 & 244.1309 & -1.8 & C 15 & H 18 & N1 & $\mathrm{O} 2$ \\
\hline & 100 & 243.1239 & 0.8 & C 15 & H 17 & $\mathrm{~N} 1$ & $\mathrm{O} 2$ \\
\hline & 6 & 229.1057 & -4.4 & C 14 & H 15 & N1 & $\mathrm{O} 2$ \\
\hline & 35 & 213.1140 & -1.2 & C 14 & H 15 & N1 & 01 \\
\hline \multirow[t]{5}{*}{3} & 16 & 403.1627 & -0.1 & $\mathrm{C} 21$ & $\mathrm{H} 25$ & N1 & O 7 \\
\hline & 39 & 258.1103 & -2.6 & C 15 & H 16 & N1 & $\mathrm{O} 3$ \\
\hline & 100 & 257.1039 & -1.1 & C 15 & H 15 & N 1 & $\mathrm{O} 3$ \\
\hline & 66 & 242.0816 & 0.0 & C 14 & $\mathrm{H} 12$ & N1 & $\mathrm{O} 3$ \\
\hline & 23 & 227.0915 & -2.9 & C 14 & H 13 & N1 & $\mathrm{O} 2$ \\
\hline \multirow[t]{5}{*}{4} & 13 & 377.1842 & 0.5 & $\mathrm{C} 20$ & $\mathrm{H} 27$ & N1 & O6 \\
\hline & 100 & 245.1423 & 0.8 & C 15 & H 19 & $\mathrm{~N} 1$ & $\mathrm{O} 2$ \\
\hline & 20 & 244.1329 & -0.7 & C 15 & H 18 & N1 & $\mathrm{O} 2$ \\
\hline & 16 & 230.1166 & -1.4 & C 14 & H 16 & N1 & $\mathrm{O} 2$ \\
\hline & 24 & 213.1125 & -2.7 & C 14 & H 15 & N1 & 01 \\
\hline
\end{tabular}

a) obtained on a Hitachi Datalyzer Hi-Resol. mass system; ion voltage $70 \mathrm{eV}$, temp. $130^{\circ}$

Heating either $\mathbf{I}$ or $\mathbf{2}$ in $1 \%$ methanolic sodium hydroxide under mild condition, gave the equilibrium mixture consisted of $\mathbf{1}$ and $\mathbf{2}$ in about 1:3 ratio, though they remained unchanged in absence of the alkali. Therefore, $\mathbf{1}$ and $\mathbf{2}$ must be epimeric with respect to the position adjacent to ketonic function, and $\mathbf{2}$ was assumed to be the thermodynamically stable isomer. Oxidation of $\mathbf{1}$ with permanganate gave a lactam identical with $\mathbf{3}$ in every respect. Thus, $\mathbf{3}$ was proved to be a $\gamma$-lactam derivable from $\mathbf{1}$.

Reduction of $\mathbf{2}$ with sodium borohydride gave a sole product, dihydroepistephamiersine (5), ${ }^{11)} \mathrm{mp} 63^{\circ}, \mathrm{mp} 133^{\circ}$ (bimorphism), $\mathrm{C}_{21} \mathrm{H}_{29} \mathrm{O}_{6} \mathrm{~N}$, m/e $391\left(\mathrm{M}^{+}\right),[\alpha]_{\mathrm{D}}^{20}+75.4^{\circ}\left(\mathrm{CHCl}_{3}\right)$. Its

10) M. Tomita, A. Kato and T. Ibuka, Tetrahedron Letters, 1965, 1019; idem, Shitsuryo Bunseki, 13,115 (1965).

11) According to Dr. A.J. van Wyk, University of Pretoria, this compound was isolated from Stephania abyssinica as a natural product and identified with authors' sample (private communication, dated May $28,1974)$. 
IR spectrum showed a hydroxyl band at $3520 \mathrm{~cm}^{-1}$, and the NMR spectrum exhibited a doublet at $\delta 2.06(J=9.5 \mathrm{~Hz})$, which disappeared by treatment with deuterium oxide, due to a secondary alcoholic proton and a multiplet centered at $\delta 4.11$ assignable to a proton on the hydroxylbearing carbon. The highly stereoselective reduction of $\mathbf{2}$ into $\mathbf{5}$ would involve the following process; the ketonic function of $\mathbf{2}$ would be attacked by hydride anion from the back-side of ketal ether bridge to give the product, $\mathbf{5}$. The configuration of this hydroxyl group will be discussed later. Similar hydride delivery has been observed in the course of the reduction of ketonic function in the ketal and hemiketal hasubanan alkaloid.s. ${ }^{12}$ )

On treatment with hydrochloric acid in methanol under mild condition $\mathbf{5}$ was transformed to 4, whose physical and spectral data were fully identical with an authentic sample. These reaction sequence revealed that $\mathbf{4}$ was a hemiketal alkaloid derivable from $\mathbf{2}$ through $\mathbf{5}$. Thus the relationship of $\mathbf{1}, \mathbf{2}, \mathbf{3}$ and $\mathbf{4}$ was chemically substantiated.

By analogy with the above reduction of $\mathbf{2}$, treatment of $\mathbf{1}$ with borohydride provided a sole product, dihydrostephamiersine $(6), \mathrm{mp} 143^{\circ}, \mathrm{C}_{21} \mathrm{H}_{29} \mathrm{O}_{6} \mathrm{~N},[\alpha]_{\mathrm{D}}^{20}+102.2^{\circ}\left(\mathrm{CHCl}_{3}\right)$. Its IR spectrum showed a hydroxyl band at $3520 \mathrm{~cm}^{-1}$, and NMR spectrum exhibited the signals of hydroxyl proton at $\delta 1.91$ as doublet $(J=11.5 \mathrm{~Hz})$ which disappeared on deuterium oxide treatment and multiplet signals centered at $\delta 3.91$ due to a proton on the hydroxyl-bearing carbon.

Acetolysis ${ }^{3 b}$ of $\mathbf{1}$ with acetic anhydride in a sealed tube gave a neutral compound (7), $\operatorname{mp~} 75^{\circ}, \mathrm{C}_{21} \mathrm{H}_{20} \mathrm{O}_{7}$, and the same treatment of $\mathbf{2}$ provided another neutral compound (8), $\mathrm{mp}$ $167^{\circ}, \mathrm{C}_{22} \mathrm{H}_{20} \mathrm{O}_{8}$. The UV spectra (Fig. 1) of $\mathbf{7}$ and $\mathbf{8}$ showed the characteristic absorption curve of the phenanthrene type chromophore, and IR spectra (Table IV) showed acetate

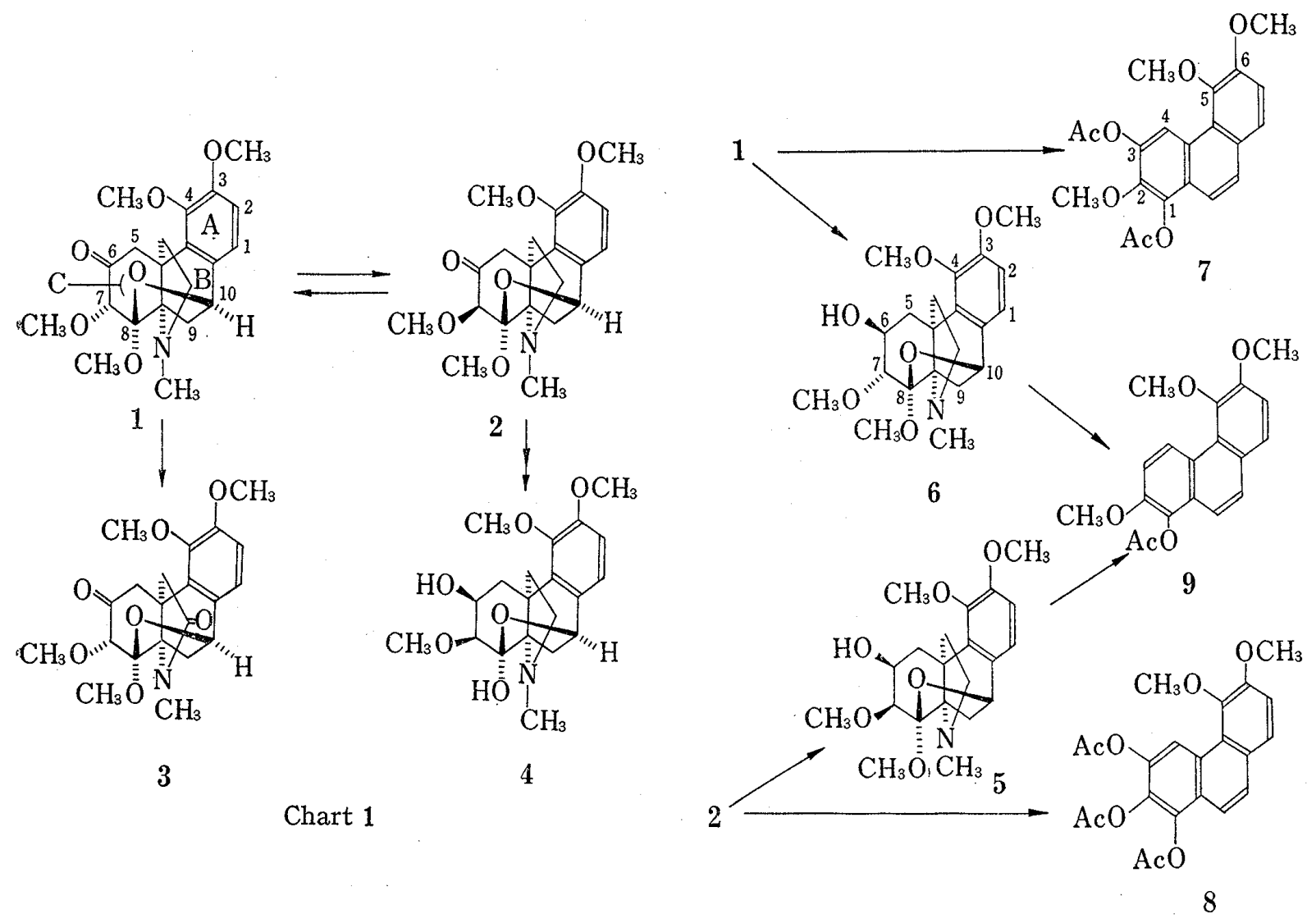

Chart 2

12) S.M. Kupchan and M.I. Suffness, Tetrahedron Letters, 1970, 4978; S.M. Kupchan, M.I. Suffness, R.J. McClure and G.A. Sim, J. Am. Chem. Soc., 92, 5756 (1970); S.M. Kupchan, A.J. Liepa and T. Fujita, J. Org. Chem., 38, 151 (1973). 
carbonyl bands. Acetolysis of either 5 or $\mathbf{6}$ afforded 1-acetoxy-2,5,6-trimethoxyphenanthrene (9), $\mathrm{mp} 139^{\circ}$, which was fully identified with an authentic sample. ${ }^{\mathbf{1 3})}$

The NMR spectra (Table IV) revealed the presence of $\mathrm{C}-4$ proton in the phenanthrenes $(\mathbf{7}, \mathbf{8}$ and 9$)$ by signals for one proton intensity at relatively low field as singlets for $\mathbf{7}$ and $\mathbf{8}$, or a doublet for $\mathbf{9}$, indicating the substitution patterns, respectively. From the unambiguous structure of $\mathbf{9}$ coupled with the NMR data and from the interrelation of the starting materials, the structures of $\mathbf{7}$ and $\mathbf{8}$ were most reasonably assigned as 1,3-diacetoxy-2,5,6-trimethoxyphenanthrene (7) and 1,2,3-triacetoxy-5,6-dimethoxyphenanthrene (8), respectively. The assignment was further supported by the well known fact that on acetolysis of morphinehasubanan series, an oxygen atom of a carbonyl group remains as acetoxyl group on the derived

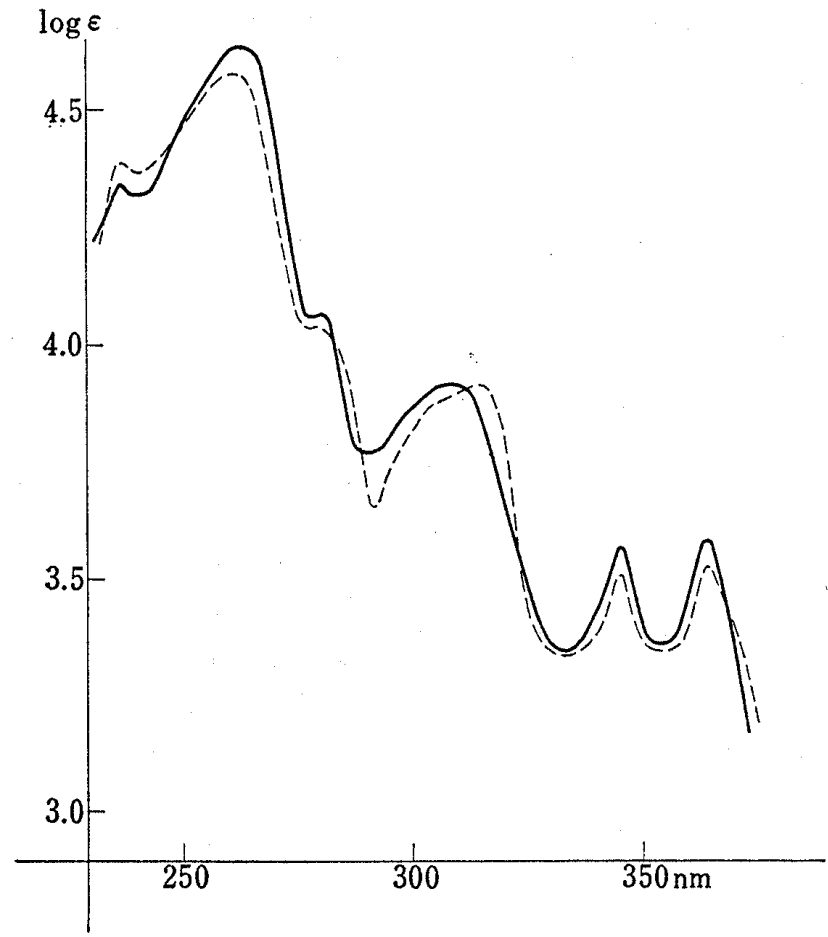

Fig. 1. Ultraviolet Absorption Spectra (in EtOH)

$:$ 1,3-diacetoxy-2,5,6-trimethoxyphenanthrene (7) : 1,2,3-triacetoxy-5,6-dimethoxyphenanthrene (8)

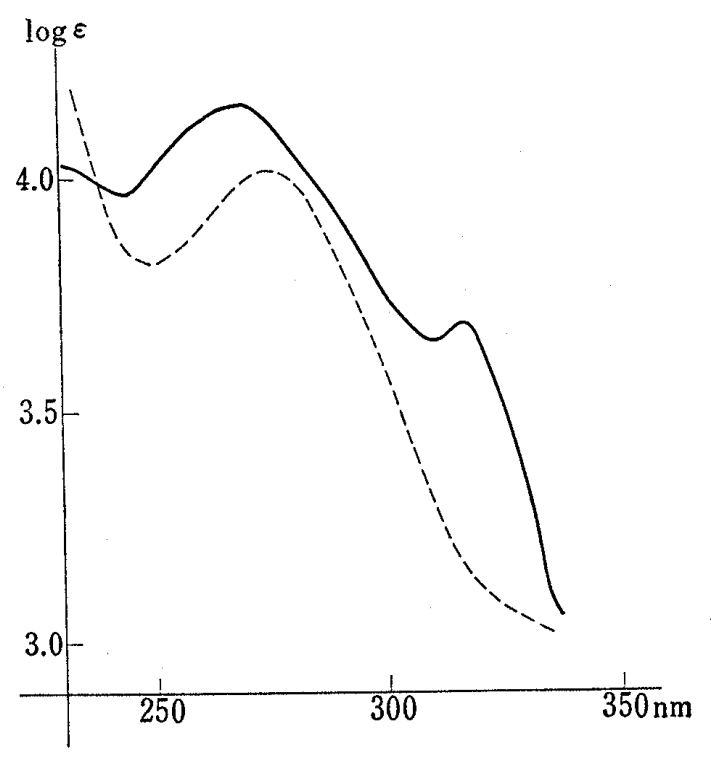

Fig. 2. Ultraviolet Absorption Spectra (in EtOH)

TABLE IV. IR and NMR Spectral Data of Phenanthrene Derivatives

\begin{tabular}{|c|c|c|c|c|}
\hline $\begin{array}{l}\text { Compd. } \\
\text { No. }\end{array}$ & $\underset{v_{\max }^{\mathrm{CHCl}_{8}} \mathrm{~cm}^{-1}}{\mathrm{IR}}$ & $\mathrm{C}(4)-\mathrm{H}$ & $\begin{array}{l}\left.\mathrm{NMR}^{a}\right) \\
\mathrm{OCH}_{3}\end{array}$ & OAc \\
\hline \multirow[t]{2}{*}{7} & \multirow[t]{2}{*}{1760} & \multirow[t]{2}{*}{$9.82(\mathrm{~s})$} & $3.97(3 \mathrm{H}, \mathrm{s})$ & $2.45(3 \mathrm{H}, \mathrm{s})$ \\
\hline & & & $3.92(6 \mathrm{H}, \mathrm{s})$ & $2.36(3 \mathrm{H}, \mathrm{s})$ \\
\hline \multirow[t]{2}{*}{8} & \multirow[t]{2}{*}{1775} & \multirow[t]{2}{*}{$9.47(\mathrm{~s})$} & $3.97(3 \mathrm{H}, \mathrm{s})$ & $2.43(3 \mathrm{H}, \mathrm{s})$ \\
\hline & & & $3.93(3 \mathrm{H}, \mathrm{s})$ & $2.33(6 \mathrm{H}, \mathrm{s})$ \\
\hline \multirow[t]{3}{*}{9} & \multirow[t]{3}{*}{1760} & \multirow{3}{*}{$\begin{array}{c}9.57(\mathrm{~d}) \\
(J=8.3 \mathrm{~Hz})\end{array}$} & $4.03(3 \mathrm{H}, \mathrm{s})$ & $2.46(3 \mathrm{H}, \mathrm{s})$ \\
\hline & & & $3.98(3 \mathrm{H}, \mathrm{s})$ & \\
\hline & & & $3.94(3 \mathrm{H}, \mathrm{s})$ & \\
\hline
\end{tabular}

a) All values are in $\delta$ units for $\mathrm{CDCl}_{3}$ solution at $60 \mathrm{MHz}$ with TMS as an internal standard. abbreviation: $\mathrm{s}=$ singlet, $\mathrm{d}=$ doublet

13) M. Tomita, T. Ibuka and Y. Inubushi, Tetrahedron Letters, 1964, 3617; M. Tomita, Y. Inubushi and T. Ibuka, Yakugaku Zasshi, 87, 381 (1967). 
phenanthrene nucleus, whereas an alcoholic hydroxyl group is eliminated by dehydration in the course of aromatization processes. ${ }^{\mathbf{1 4})}$

The result of acetolyses of $\mathbf{1}$ and $\mathbf{2}$ together with the foregoing arguments disclosed that the ketonic function was situated at C-6 position of the hasubanan system, and remnant one oxygen and one methoxyl group should be assigned to a ketal ether and ketal methoxyl at C-8 position. The conversion of $\mathbf{2}$ into $\mathbf{4}$ also presented a chemical support to this ketal methoxyl assignment.

Furthermore, the NMR spectra of $\mathbf{1}, \mathbf{2}, \mathbf{3}$ and $\mathbf{4}$ exhibited doublet signals attribulable to C-10 proton at $\delta 4.72-4.88(J=6.5 \mathrm{~Hz})$. In case of $\mathbf{2}$, a nuclear Overhauser effect (NOE) $(13 \%)$ was observed at this doublet $(\delta 4.82)$ by irradiating aromatic proton signal $(\delta 6.66)$, and the signals at $\delta 1.47$ (doublet, $J=10.5 \mathrm{~Hz}$ ) and at $\delta 2.64$ (double doublet, $J_{1}=10.5 \mathrm{~Hz}$, $J_{2}=6.5 \mathrm{~Hz}$ ) were assigned to C-9 methylene protons by double resonance technique. From these assignments, it follows that the ketal ether should link C-8 and C-10.

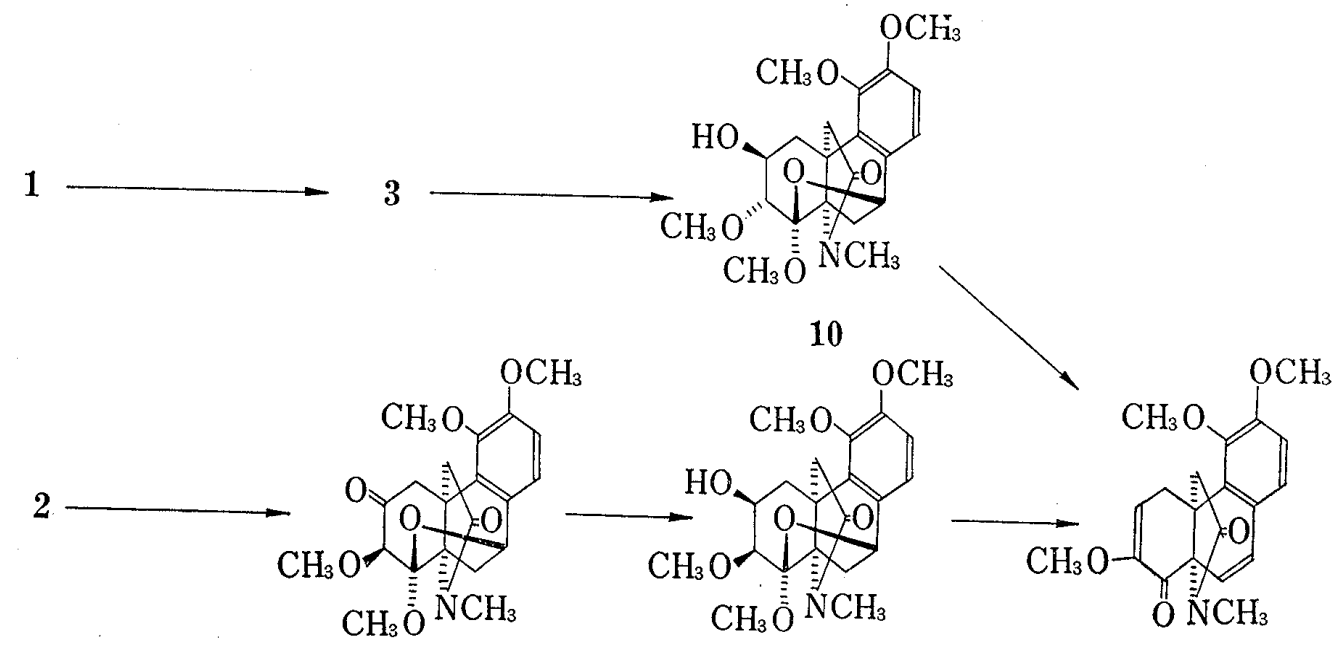

12

13

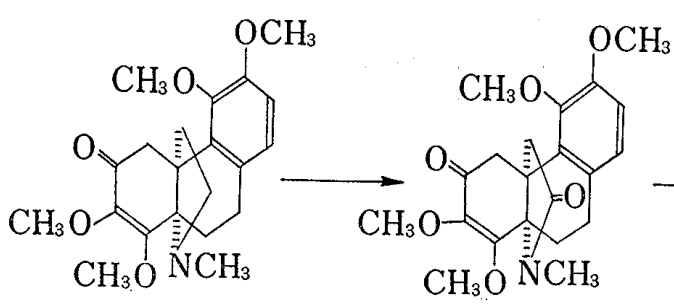

15

16

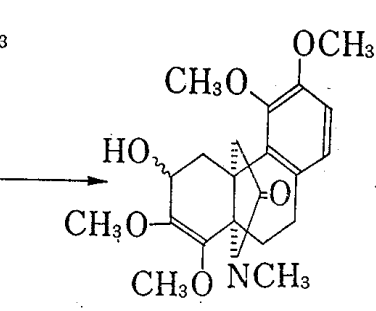

$17 a, b$,
11

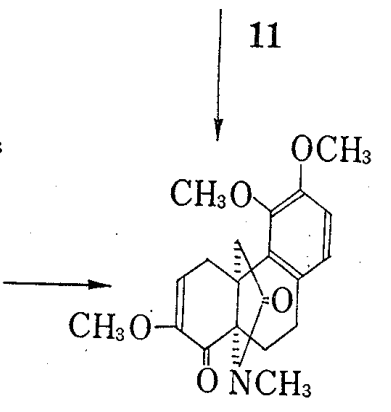

14

Chart 3

Though the above chemical and spectral evidences gave the two-dimensional formulas of $\mathbf{1}, \mathbf{2}, \mathbf{3}$ and 4 , these structures were verified by correlation to hasubanonine (15). ${ }^{15}$ )

Reduction of $\mathbf{3}$ with sodium borohydride gave dihydrooxostephamiersine $(\mathbf{1 0}), \mathrm{mp} 236^{\circ}$, $\mathrm{C}_{21} \mathrm{H}_{27} \mathrm{O}_{7} \mathrm{~N}, m / e 405\left(\mathrm{M}^{+}\right)$. On treatment with acetic anhydride-perchloric acid in ethyl acetate, $\mathbf{1 0}$ was converted to a compound (11), mp $157^{\circ}, \mathrm{C}_{20} \mathrm{H}_{21} \mathrm{O}_{5} \mathrm{~N}, m / e 355\left(\mathrm{M}^{+}\right)$. Its UV spectrum (Fig. 2) showed an absorption curve of the styrene type chromophore, and the IR spectrum

14) E. Leete, J. Am. Chem. Soc., 81, 3948 (1959).

15) a) H. Kondo, M. Satomi and T. Odera, Itsuu Kenkyusho Nempo, 2, $35(1951)$; b) M. Tomita, T. Ibuka, Y. Inubushi, Y. Watanabe and M. Matsui, Tetrahedron Letters, 1964, 2937; idem, Chem. Pharm. Bull. (Tokyo), 13, 538 (1965). 
exhibited the bands of conjugated ketone and double bond at $1680 \mathrm{~cm}^{-1}$ and $1640 \mathrm{~cm}^{-1}$, respectively. The NMR spectrum revealed three methoxyl groups at $\delta 3.96,3.86$ and 3.62 as singlets, and C-6 olefinic proton at $\delta 5.96$ as a double doublet $\left(J_{1}=7.2 \mathrm{~Hz}, J_{2}=3.5 \mathrm{~Hz}\right)$, besides $\mathrm{C}-9$ and $\mathrm{C}-10$ olefinic protons at $\delta 5.72$ and 6.80 as doublets $(J=9.5 \mathrm{~Hz})$. These spectral data suggested that $\mathbf{1 0}$ underwent the fission of the ketal ether followed by dehydration involving hydroxyl groups at C-6 and C-10. Therefore, 11 possesses C-9, C-10 double bond in conjugation with the benzene ring and $\mathrm{C}-6, \mathrm{C}-7$ double bond conjugated with the ketonic function. The above result gave a chemical support of the presence of ketal moiety between $\mathrm{C}-8$ and $\mathrm{C}-10$.

Oxidation of 2 with permanganate gave oxoepistephamiersine (12), mp $228^{\circ}, \mathrm{C}_{21} \mathrm{H}_{25} \mathrm{O}_{7} \mathrm{~N}$, m/e $403\left(\mathrm{M}^{+}\right)$, which on reduction with sodium borohydride gave dihydrooxoepistephamiersine (13), $\mathrm{mp} 234^{\circ}, \mathrm{C}_{21} \mathrm{H}_{27} \mathrm{O}_{7} \mathrm{~N}, m / e 405\left(\mathrm{M}^{+}\right)$. On treatment with acetic anhydride-perchloric acid, 13 also afforded 11.

Catalytic hydrogenation of $\mathbf{1 1}$ over palladized charcoal gave a compound (14), $\mathrm{mp} 171^{\circ}$, $\mathrm{C}_{20} \mathrm{H}_{23} \mathrm{O}_{5} \mathrm{~N}, m / e 357\left(\mathrm{M}^{+}\right),[\alpha]_{\mathrm{D}}^{23}-143^{\circ}\left(\mathrm{CHCl}_{3}\right)$. Its UV spectrum (Fig. 2) showed no absorption maximum at around $315 \mathrm{~nm}$. Its IR spectrum exhibited bands at $1680 \mathrm{~cm}^{-1}$ and $1640 \mathrm{~cm}^{-1}$, and the NMR spectrum revealed only one olefinic proton centered at $\delta 5.81$ (double doublet, $J_{1}=6.0 \mathrm{~Hz}, J_{2}=3.5 \mathrm{~Hz}$ ). The above results demonstrated that $\mathbf{1 1}$ was hydrogenated at $\mathrm{C}-9, \mathrm{C}-10$ double bond to give $\mathbf{1 4}$.

Reduction of 16 -oxohasubanonine $(\mathbf{1 6})^{16}$ ) with sodium borohydride followed by alumina column chromatography gave C-6 epimeric alcohols, dihydro-16-oxohasubanonine-A (17a) and dihydro-16-oxohasubanonine-B (17b). The NMR spectra and chromatographic behavior of $\mathbf{1 7 a}$ and $\mathbf{1 7 b}$ indicated that hydroxyl group of the former has the quasi-axial configuration and that of the latter has the quasi-equatorial one, as with the case previously reported on dihydrohasubanonine. ${ }^{15 b}$ ) On treatment of either $\mathbf{1 7 a}$ or $\mathbf{1 7 b}$ with $1 \%$ hydrobromic acid gave a product identical with $\mathbf{1 4}$ in every respect.

In view of the above facts, $\mathbf{1}, \mathbf{2}, \mathbf{3}$ and $\mathbf{4}$ possess the hasubanan skeleton, and the ketal ether or hemiketal ether bridge must be $\beta$-oriented, hence the methoxyl or hydroxyl group on $\mathrm{C}-8$ and the hydrogen on $\mathrm{C}-10$ must be $\alpha$-oriented. Consequently, in case of $\mathbf{2}$ for example, C-9 methylene proton chemical shifts discussed earlier and their stereochemistry were assigned as follows: the higher field doublet $(\delta 1.47)$ is for $\alpha$ - and the lower field double doublet $(\delta 2.64)$ is for $\beta$-proton, respectively.

The absolute stereostructures of $\mathbf{1}, \mathbf{2}, \mathbf{3}$ and $\mathbf{4}$ were verified by the following NMR examination. ${ }^{17)}$ The NMR spectrum of $\mathbf{1}$ revealed $\mathrm{C}-5$ methylene protons at $\delta 2.86$ ( $\beta$-equatorial proton, double doublet, $J_{1}=11.5 \mathrm{~Hz}, J_{2}=1.5 \mathrm{~Hz}$ ) and $\delta 3.67$ ( $\alpha$-axial proton, doublet, $J=$ $11.5 \mathrm{~Hz}$ ). The homonuclear internuclear double resonance (INDOR) spectra showed that this higher field proton $(\delta 2.86)$ couples with $\mathrm{C}-7$ proton $(\delta 3.52$, doublet, $J=1.5 \mathrm{~Hz})$ in a long range interproton coupling ( $4 \sigma$-bond coupling) according to W-rule. ${ }^{18)}$ While, 2 showed the signals of C-5 methylene protons at $\delta 2.99$ ( $\beta$-equatorial proton) and $\delta 3.18$ ( $\alpha$-axial proton) as each doublet $(J=11.5 \mathrm{~Hz})$. Irradiation at the lower field proton $(\delta 3.18)$ gave a $6.5 \% \mathrm{NOE}$ enhancement of C-7 proton signal $(\delta 4.27)$, but irradiation upon the higher field proton $(\delta 2.99)$ gave no signal enhancement of the C-7 proton signal. These NMR findings together with the foregoing results of the equilibrium reaction in alkali, disclosed the $\mathrm{C}-7$ configuration of $\mathbf{1}$ and $\mathbf{2}$ as drawn in projection $\mathbf{1}^{\prime}$ and $\mathbf{2}^{\prime}$ (Fig. 3). Consequently, it has been assigned that

16) T. Ibuka, K. Tanaka and Y. Inubushi, Tetrahedron Letters, 1970, 4811; idem, Chem. Pharm. Bull. (Tokyo), 22, 782 (1974).

17) The spectra were taken on a Varian HA-100D spectrometer.

18) K.B. Wiber, B.R. Lowry and B.J. Nist, J. Am. Chem. Soc., 84, 1594 (1962); A. Rassat, C.W. Jefford, J.M. Lehn and B. Waegell, Tetrahedron Letters, 1964, 233 ; L.M. Jackman and S. Sternhell, "Application of Nuclear Magnetic Resonance Spectroscopy in Organic Chemistry," 2nd Edition, Pergamon Press, New York, 1969, pp. 334-341. 


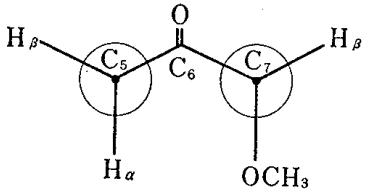
$1^{\prime}$

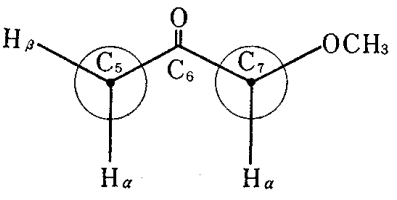

$2^{\prime}$

Fig. 3. Projection Formulas of Stephamiersine (1) and Epistephamiersine (2) about C-5, C-6 and C-7 Substituents

$\mathbf{1}^{\prime}$ : stephamiersine $\mathbf{2}^{\prime}$ : epistephamiersine

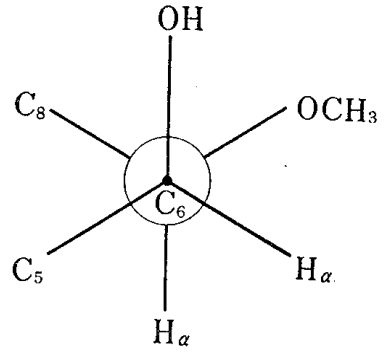

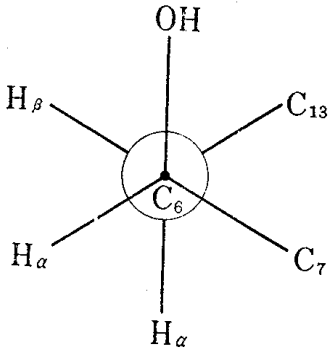

Fig. 4. Projection Formulas of Stephasunoline (4)

The left view is along the $\mathrm{C}_{6}-\mathrm{C}_{7}$ axis and the right is along the $\mathrm{C}_{6}-\mathrm{C}_{5}$ axis.

C-7 methoxyl group of $\mathbf{1}$ has the $\alpha$-axial configuration and that of $\mathbf{2}$ has the $\beta$-equatorial one. The NMR spectrum of 4 exhibited the signals of C-5 methylene protons at $\delta 2.46\left(J_{1}=\right.$ $\left.14.3 \mathrm{~Hz}, J_{2}=2.4 \mathrm{~Hz}\right)$ and $\delta 2.82\left(J_{1}=14.3 \mathrm{~Hz}, J_{2}=3.8 \mathrm{~Hz}\right)$ as each double doublet, and C-7 proton signal ( $\delta 3.62$, doublet, $J=3.9 \mathrm{~Hz}$ ) enhancement $(12 \%)$ was observed upon irradiation of the higher field methylene proton $(\delta 2.46)$. The NOE combined with the coupling constant values of C-5, C- 6 and C-7 proton displayed the C-6 configuration of 4 as drawn in projection $4^{\prime}$ (Fig. 4). Thus, it has been determined that the C-6 hydroxyl group has a $\beta$-axial configuration and $\mathrm{C}-7$ methoxyl group has a $\beta$-equatorial one.

The stereochemistry of C-6 hydroxyl groups in the foregoing highly stereoselective reduction products, 5, 6, 10 and $\mathbf{1 3}$ was elucidated by the coupling constant values on NMR. Each coupling constant values $(2.3-2.9 \mathrm{~Hz})$ between $\mathrm{C}-5$ methylene protons and $\mathrm{C}-6$ proton was found to be indicative of axial-equatorial or equatorial-equatorial coupling, and none was found to be for diaxial coupling. Therefore, the C-6 hydroxyl groups of $\mathbf{5 , 6}, \mathbf{1 0}$ and $\mathbf{1 3}$ should have the $\beta$-axial configuration, respectively.

On the basis of the chemical and spectral evidences stated above, the constitution of stephamiersine (1), epistephamiersine (2), oxostephamiersine (3) and stephasunoline (4) was unambiguously represented as drawn in the formulas including their absolute stereostructures.

\section{Experimental}

Melting points were determined on a Yanaco micro melting point apparatus and uncorrected. UV, IR and mass spectra were taken on a Shimadzu MPS-50L, Hitachi EPI-G 3, Hitachi EPI-S 2, Hitachi R MU-7M and JEOL JMS-D 100 spectrometer. NMR spectra were measured on a Hitachi Perkin-Elmer R-20A, Hitachi Perkin-Elmer R-22 and Varian HA-100D spectrometer in $\mathrm{CDCl}_{3}$ solution with tetramethylsilane (TMS) as an internal standard, and chemical shifts were given in $\delta$ value. The abbreviation, $\mathrm{s}, \mathrm{d}$, dd and $\mathrm{m}$ in the NMR spectra signify singlet, doublet, double doublet and multiplet. Optical rotations were measured on a Yanaco OR-10 and JASCO DIP-4 polarimeter. Column chromatography was effected using Brockmann neutral alumina activity II-III or Mallinckrodt silicic acid (100 mesh). Thin-layer chromatography (TLC) was performed on Aluminiumoxid G nach Stahl or Kieselgel G nach Stahl using indicated solvents and spots were detected by treatment with vapor of iodine and spraying Dragendorff's reagent.

Extraction and Fractionation of Alkaloids_- The dried chipped stems and rizomes (79 $\mathrm{kg})$ of Stephania japonica MIERs collected in February 1970 at Bohnotsu-cho, Kagoshima Prefecture, were extracted three times with $\mathrm{MeOH}$ at reflux for $8 \mathrm{hr}$ under mechanical stirring and the solvent was evaporated under reduced pressure. The residue $(9 \mathrm{~kg}$ ) was digested five times with an aqueous citric acid solution adjusted to $\mathrm{pH} 2-3$ during $6 \mathrm{hr}$ at $60-70^{\circ}$. The acid solution (90 liters) was shaken with $\mathrm{CHCl}_{3}$ (total of 120 liters) to yield the "weak base fraction." The remaining acid layer was made alkaline to $\mathrm{pH} 9-\mathbf{1 0}$ with dil. $\mathrm{NH}_{4} \mathrm{OH}$ and was shaken with $\mathrm{CHCl}_{3}$ (total of 95 liters) to yield the "strong base fraction." i) The "weak base fraction" was shaken with $2 \% \mathrm{NaOH}$ (total of 60 liters) and the residual $\mathrm{CHCl}_{3}$ layer, after being washed with water and dried over $\mathrm{MgSO}_{4}$, was evaporated to give a crude non-phenolic extract $(1.2 \mathrm{~kg})$. The aqueous layer was acidified with $5 \% \mathrm{AcOH}$, made alkaline with dil. $\mathrm{NH}_{4} \mathrm{OH}$ and extracted with $\mathrm{CHCl}_{3}$. The $\mathrm{CHCl}_{3}$ extract was washed, dried over $\mathrm{MgSO}_{4}$ and evaporated to give a crude phenolic extract (230 g). ii) The "strong base 
fraction" was worked up by the same manner as in i) to give a phenolic $(700 \mathrm{~g})$ and a non-phenolic extract $(1.8 \mathrm{~kg})$.

Isolation of Alkaloids_-i) Non-phenolic Bases from the "Weak Base Fraction": The crude extract $(1.2 \mathrm{~kg})$ was chromatographed over alumina column $(5.5 \times 98 \mathrm{~cm})$ from benzene and eluted successively with benzene, benzene-ether (1:1), benzene-AcOEt (1:1), AcOEt, AcOEt-CHCl $(1: 1), \mathrm{CHCl}_{3}, \mathrm{CHCl}_{3}-\mathrm{EtOH}_{3}$ $(99: 1)$ and $\mathrm{CHCl}_{3}-\mathrm{EtOH}(1: 1)$. a) The fractions eluted with benzene, benzene-ether $(1: 1)$, benzene-AcOEt $(1: 1)$ and AcOEt were evaporated to dryness. The residues were combined and rechromatographed over silica gel column $(5.5 \times 95 \mathrm{~cm})$ by eluting successively with $\mathrm{CHCl}_{3}, \mathrm{CHCl}_{3}-\mathrm{EtOH}(99: 1)$ and $\mathrm{CHCl}_{3}-\mathrm{EtOH}$ $(1: 1)$. Elution with $\mathrm{CHCl}_{3}$ and with $\mathrm{CHCl}_{3}-\mathrm{EtOH}(99: 1)$ gave the mixture of stephamiersine (1), epistephamiersine (2) and oxostephamiersine (3) as a brownish solid which was crystallized from $\mathrm{MeOH}$ to give 3 as slightly yellow crystals. Recrystallization from $\mathrm{MeOH}$ gave $12.7 \mathrm{~g}$ of 3 as colorless prisms, $\mathrm{mp} 290^{\circ}, 256^{\circ}$ bimorphism). The methanolic mother liquor gave a mixture of 1 and 2 as a slightly yellow solid. Recrystallization from $\mathrm{MeOH}$ gave the mixture of 1 and 2 as colorless prisms, ${ }^{19}$ ) which was dissolved in $\mathrm{MeOH}$ and $1 \% \mathrm{HNO}_{3}$ was added gradually with cooling. After filtration of 2 nitrate deposited at first, the mother liquor was allowed to stand at room temperature for a few hours to give 1 nitrate. The nitrates were recrystallized from $\mathrm{MeOH}$, and 1 nitrate ( $\mathrm{mp} 240^{\circ}$ (decomp.)) and 2 nitrate ( $\mathrm{mp} 212^{\circ}$ (decomp.)) were obtained. They were worked up by the usual way to afford the free bases, $1\left(\mathrm{mp} 165^{\circ}(\mathrm{MeOH}), 2.1 \mathrm{~g}\right)$ and 2 ( $\mathrm{mp} 98^{\circ}$ $(\mathrm{MeOH}), 8.3 \mathrm{~g})$. b) The eluate with $\mathrm{AcOEt}-\mathrm{CHCl}_{3}$ on the foregoing alumina column chromatography was evaporated to dryness and the residue was rechromatographed over silica gel column $(3 \times 42 \mathrm{~cm}) \mathrm{from}_{\mathrm{CHCl}}$ and elution with the same solvent gave $860 \mathrm{mg}$ of metaphanine, ${ }^{3)} \mathrm{mp} 232^{\circ}$ (acetone-CHCl$)_{3}$ ), $[\alpha]_{\mathrm{b}}^{22}-42.7^{\circ}$ $\left(c=1.65, \mathrm{CHCl}_{3}\right)$. c) The eluate with $\mathrm{CHCl}_{3}$ on the foregoing alumina column chromatography was also rechromatographed over silica gel column $(3.5 \times 36 \mathrm{~cm})$ from $\mathrm{CHCl}_{3}$ and elution with the same solvent gave $1.2 \mathrm{~g}$ of stephanine, ${ }^{4)} \mathrm{mp} 155-156^{\circ}$ (acetone), $[\alpha]_{\mathrm{D}}^{20}-88.3^{\circ}\left(c=1.0, \mathrm{CHCl}_{3}\right)$. The mother liquor of stephanine, after being evaporated to dryness, was rechromatographed over alumina column from benzene and elution with benzene and with AcOEt gave $280 \mathrm{mg}$ of base-P (unidentified) as colorless prisms (MeOH), $\mathrm{mp} 195^{\circ}$. d) The fractions eluted from the foremost alumina column with $\mathrm{CHCl}_{3}-\mathrm{EtOH}(99: 1)$ and $\mathrm{CHCl}_{3}-\mathrm{EtOH}$ (1:1) were combined with the mother liquors of the crystalline bases, and then the solvent was evaporated. The residue was rechromatographed over alumina column $(3.5 \times 38 \mathrm{~cm})$ by eluting successively with benzene, AcOEt and $\mathrm{CHCl}_{3}$. Elution with AcOEt gave $160 \mathrm{mg}$ of base-X (unidentified) as orange-yellow pillars $\left(\mathrm{CHCl}_{3}\right), \mathrm{mp} 316-318^{\circ}$ (decomp.), and elution with $\mathrm{CHCl}_{3}$ gave $420 \mathrm{mg}$ of base-S (unidentified) as yellow pillars $\left(\mathrm{CHCl}_{3}\right), \mathrm{mp} 270-272^{\circ}$.

ii) Phenolic Bases from the "Weak Base Fraction": The extract $(230 \mathrm{~g})$ was worked up by the multibuffered extraction $\left.{ }^{20}\right)$ ( $\mathrm{pH} 4.8,3.4$ and 2.4) followed by chromatography over silica gel column from $\mathrm{CHCl}_{3}$. Hypoepistephanine, ${ }^{5)} \mathrm{mp} 256^{\circ}(\mathrm{MeOH}),[\alpha]_{\mathrm{D}}^{20}+181.1^{\circ}(c=1.36, \mathrm{MeOH}), 1.2 \mathrm{~g}$ was crystallized, but the mother liquor was not investigated further.

iii) Non-phenolic Bases from the "Strong Base Fraction": The extract $(1.2 \mathrm{~kg})$ was dissolved in $\mathrm{CHCl}_{3}$ (10 liters) and the solution was shaken successively with MacIlvain buffer solution ${ }^{19)}$ (double strength) of $\mathrm{pH} 5.8,4.6,3.2$ and 2.6. The residual $\mathrm{CHCl}_{3}$ layer, after being washed with $2 \% \mathrm{Na}_{2} \mathrm{CO}_{3}$ and water, was evaporated to dryness and the residue was extracted with $3 \%$ AcOH at $50-60^{\circ}$. Each extract was made alkaline with dil. $\mathrm{NH}_{4} \mathrm{OH}$ and extracted with ether. The ethereal solutions were washed with water, dried over $\mathrm{MgSO}_{4}$ and evaporated to dryness, a) The extract (485 g) from the buffer solution of $\mathrm{pH} 5.8$ was chromatographed over alumina column $(5 \times 82 \mathrm{~cm})$ from benzene and elution with the same solvent gave a crystalline solid. Recrystallization from $\mathrm{MeOH}$ gave $25 \mathrm{~g}$ of epistephanine, ${ }^{6)} \mathrm{mp} 203-204^{\circ},[\alpha]_{\mathrm{D}}^{24}+184.8^{\circ}$ $\left(c=1.33, \mathrm{CHCl}_{3}\right)$. The mother liquor of epistephanine, after being concentrated, was allowed to stand in a refrigerator overnight to afford a crystalline solid which was recrystallized from $\mathrm{MeOH}$ to give $350 \mathrm{mg}$ of stebisimine, $\left.{ }^{8}\right) \mathrm{mp} 233^{\circ},[\alpha]_{\mathrm{D}}^{26} \pm 0^{\circ}(c=0.97, \mathrm{MeOH})$. b) The extract $(360 \mathrm{~g})$ from the buffer solution of $\mathrm{pH} 4.6$ was chromatographed over alumina column from benzene and elution with the same solvent gave additional amount of epistephanine $(360 \mathrm{mg})$ and stebisimine $(42 \mathrm{mg})$. c) The extract $(318 \mathrm{~g})$ from the buffer solution of pH 3.2 was chromatographed over alumina column $(3.5 \times 45 \mathrm{~cm})$ by eluting successively with benzene, benzene-AcOEt $(1: 1)$, AcOEt, $\mathrm{CHCl}_{3}$ and $\mathrm{CHCl}_{3}-\mathrm{EtOH}(9: 1)$. Elution with benzene and with benzeneAcOEt $(1: 1)$ gave $280 \mathrm{mg}$ of epistephanine, and the fractions eluted with $\mathrm{AcOEt} \mathrm{CHCl}_{3}$ and $\mathrm{CHCl}_{3}-\mathrm{EtOH}$ $(9: 1)$ gave $18 \mathrm{~g}$ of protostephanine, ${ }^{7)} \mathrm{mp} 73-74^{\circ}(\mathrm{MeOH}),[\alpha]_{\mathrm{p}}^{26} \pm 0^{\circ}(c=1.46, \mathrm{MeOH})$. d) The extract $(255 \mathrm{~g})$ obtained from the buffer solution of $\mathrm{pH} 2.6$ was chromatographed over alumina column from benzene and eluted with AcOEt, and then with $\mathrm{CHCl}_{3}$. After the solvents were evaporated, the combined residue triturated with $\mathrm{MeOH}$ to give a crystalline solid which was recrystallized from the same solvent to afford $180 \mathrm{mg}$ of stephasunoline (4) as colorless pillars. e) The extract (98 g) from the AcOH extraction was not investigated further.

19) This mixture, under the tentative name of XII-base was presented at 16th Annual Meeting of Pharmaceutical Society of Japan, Shizuoka, Nov. 1962; cf. Abstracts of Papers, p. 211.

20) Y. Watanabe, M. Uchiyama and K. Yasuda, Yakugaku Zasshi, 77, 807 (1957). 
iv) Phenolic Bases from the "Strong Base Fraction": The extract $(700 \mathrm{~g})$ was dissolved in $\mathrm{CHCl}_{3}$ (8 liters) and the solution was shaken with MacIlvain buffer solution ${ }^{20}$ ) (double strength) of pH 5.0. The aqueous layer was made alkaline with dil. $\mathrm{NH}_{4} \mathrm{OH}$ and extracted with $\mathrm{CHCl}_{3}$. The $\mathrm{CHCl}_{3}$ extract, after being washed with water and dried over $\mathrm{MgSO}_{4}$, was evaporated to dryness. The residue was dissolved in $\mathrm{MeOH}$-ether and the solution was let stand in a refrigerator for several days to give a crystalline mass. Recrystallization from $\mathrm{MeOH}$ gave $38 \mathrm{~g}$ of hypoepistephanine. The $\mathrm{CHCl}_{3}$ layer of the above buffer extraction was extracted with the buffer solution of $\mathrm{pH} 3.6$, and the aqueous layer was worked up by the same manner as that described above to give $5.5 \mathrm{~g}$ of hypoepistephanine. The residual $\mathrm{CHCl}_{3}$ solution was extracted with the buffer solution of $\mathrm{pH} 2.8$, and the aqueous layer was worked up by the usual method to give $740 \mathrm{mg}$ of stepinonine, ${ }^{9)} \mathrm{mp} 280^{\circ}(\mathrm{MeOH}),[\alpha]_{\mathrm{D}}^{20}-28.3^{\circ}\left(c=0.87, \mathrm{CHCl}_{3}\right)$.

Stephamiersine (1) (New Base)-Colorless prisms (MeOH), mp $165^{\circ} ;[\alpha]_{\mathrm{D}}^{20}+33.0^{\circ}\left(c=1.28, \mathrm{CHCl}_{3}\right)$. Anal. Calcd. for $\mathrm{C}_{21} \mathrm{H}_{27} \mathrm{O}_{6} \mathrm{~N}: \mathrm{C}, 64.76 ; \mathrm{H}, 6.99 ; \mathrm{N}, 3.60$. Found: $\mathrm{C}, 64.82 ; \mathrm{H}, 7.16 ; \mathrm{N}, 3.63$. Mass Spectrum $m / e: 389\left(\mathrm{M}^{+}\right), 244,243$ (base peak), 229, 213. UV $\lambda_{\max }^{\mathrm{EtoH}} \mathrm{nm}(\varepsilon): 286(2200)$. IR $\nu_{\max }^{\mathrm{CHCl}_{3}} \mathrm{~cm}^{-1}: 1725$ (six-membered $\mathrm{C}=\mathrm{O})$. NMR: $6.67(2 \mathrm{H}$, s, aromatic $\mathrm{H}), 4.72(1 \mathrm{H}, \mathrm{d}, J=6.5 \mathrm{~Hz}, \mathrm{C}(10)-\mathrm{H}), 3.52(1 \mathrm{H}, \mathrm{d}, J=1.5 \mathrm{~Hz}$, $\mathrm{C}(7)-\mathrm{H}), 3.92,3.82,3.34,3.31\left(\right.$ each $\left.3 \mathrm{H}, \mathrm{s}, 4 \times \mathrm{OCH}_{3}\right), 2.64\left(3 \mathrm{H}, \mathrm{s}, \mathrm{NCH}_{3}\right), 1.86\left(1 \mathrm{H}, \mathrm{d}, J=10.5 \mathrm{~Hz}, \mathrm{C}(9)-\mathrm{H}_{\alpha}\right)$. Yield, $2.1 \mathrm{~g}$. TLC: Rf $0.64\left(\mathrm{Al}_{2} \mathrm{O}_{3}, \mathrm{CHCl}_{3}\right)$. Hydriodide: mp $253^{\circ}$ (decomp.) (MeOH). Anal. Calcd. for $\mathrm{C}_{21} \mathrm{H}_{27} \mathrm{O}_{6} \mathrm{~N} \cdot \mathrm{HI} \cdot 1 / 2 \mathrm{H}_{2} \mathrm{O}: \mathrm{C}, 47.92 ; \mathrm{H}, 5.55 ; \mathrm{N}, 2.67$. Found: C, 47.68; H, 5.39; N, 2.65. Nitrate: $\mathrm{mp} 240^{\circ}$ (decomp.) (MeOH). Anal. Calcd, for $\mathrm{C}_{21} \mathrm{H}_{27} \mathrm{O}_{6} \mathrm{~N} \cdot \mathrm{HNO}_{3}: \mathrm{C}, 55.74 ; \mathrm{H}, 6.24 ; \mathrm{N}, 6.19$. Found: C, 55.97; $\mathrm{H}, 6.51 ; \mathrm{N}, 5.93$.

Epistephamiersine (2) (New Base)-Colorless prisms (MeOH), mp 98,$[\alpha]_{\mathrm{D}}^{20}+64.1^{\circ}\left(c=1.12, \mathrm{CHCl}_{3}\right)$. Anal. Calcd. for $\mathrm{C}_{21} \mathrm{H}_{27} \mathrm{O}_{6} \mathrm{~N}: \mathrm{C}, 64.76 ; \mathrm{H}, 6.99 ; \mathrm{N}, 3.60$. Found: $\mathrm{C}, 64.95 ; \mathrm{H}, 6.82 ; \mathrm{N}, 3.60$. Mass Spectrum $m / e: 389\left(\mathrm{M}^{+}\right), 244,243$ (base peak), 228, 213. UV $\lambda_{\max }^{\mathrm{EtoH}} \mathrm{nm}(\varepsilon): 286(2300)$. IR $\nu_{\max }^{\mathrm{CHCl}_{3}} \mathrm{~cm}^{-1}: 1735$ (six-membered $\mathrm{C}=\mathrm{O})$. NMR: $6.66(2 \mathrm{H}, \mathrm{s}$, aromatic $\mathrm{H}), 4.82(1 \mathrm{H}, \mathrm{d}, J=6.5 \mathrm{~Hz}, \mathrm{C}(10)-\mathrm{H}), 4.27(1 \mathrm{H}, \mathrm{s}, \mathrm{C}(7)-\mathrm{H}), 3.89$, 3.76, 3.52, 3.45 (each $\left.3 \mathrm{H}, \mathrm{s}, 4 \times \mathrm{OCH}_{3}\right), 2.63\left(3 \mathrm{H}, \mathrm{s}, \mathrm{NCH}_{3}\right), 1.47\left(1 \mathrm{H}, \mathrm{d}, J=10.5 \mathrm{~Hz}, \mathrm{C}(9)-\mathrm{H}_{\alpha}\right)$. Yield, $8.3 \mathrm{~g}$. TLC: Rf $0.53\left(\mathrm{Al}_{2} \mathrm{O}_{3}, \mathrm{CHCl}_{3}\right)$. Hydriodide: $\mathrm{mp} 217^{\circ}$ (decomp.) (MeOH). Anal. Calcd. for $\mathrm{C}_{21} \mathrm{H}_{27} \mathrm{O}_{6} \mathrm{~N} \cdot \mathrm{HI}$ : $\mathrm{C}, 48.75 ; \mathrm{H}, 5.46 ; \mathrm{N}, 2.71$. Found: $\mathrm{C}, 48.98 ; \mathrm{H}, 5.34 ; \mathrm{N}, 2.68$. Nitrate: $\mathrm{mp} 212^{\circ}$ (decomp.) (MeOH). Anal. Calcd. for $\mathrm{C}_{21} \mathrm{H}_{27} \mathrm{O}_{6} \mathrm{~N} \cdot \mathrm{HNO}_{3}: \mathrm{C}, 55.74 ; \mathrm{H}, 6.24 ; \mathrm{N}, 6.19$. Found: $\mathrm{C}, 55.62 ; \mathrm{H}, 5.98 ; \mathrm{N}, 6.07$. Methiodide: mp $181^{\circ}$ (decomp.) (MeOH). Anal. Calcd. for $\mathrm{C}_{21} \mathrm{H}_{27} \mathrm{O}_{6} \mathrm{~N} \cdot \mathrm{CH}_{3} \mathrm{I}: \mathrm{C}, 49.73 ; \mathrm{H}, 5.69 ; \mathrm{N}, 2.64$. Found: $\mathrm{C}, 49.96$; $\mathrm{H}, 5.43 ; \mathrm{N}, 2.62$. Oxime: $\operatorname{mp} 141^{\circ}(\mathrm{EtOH})$. Anal. Calcd. for $\mathrm{C}_{21} \mathrm{H}_{28} \mathrm{O}_{6} \mathrm{~N}_{2}: \mathrm{C}, 62.36 ; \mathrm{H}, 6.98 ; \mathrm{N}, 6.93$. Found: C, $62.61 ; \mathrm{H}, 5.82 ; \mathrm{N}, 6.75$.

Oxostephamiersine (3) (New Base)_CColorless prisms (MeOH), mp 290 $256^{\circ}$ (bimorphism), $[\alpha]_{\mathrm{D}}^{27}+88.25^{\circ}$ $\left(c=1.87, \mathrm{CHCl}_{3}\right)$. Anal. Calcd. for $\mathrm{C}_{21} \mathrm{H}_{25} \mathrm{O}_{7} \mathrm{~N}: \mathrm{C}, 62.52 ; \mathrm{H}, 6.25 ; \mathrm{N}, 3.47$. Found: C, 62.34; $\mathrm{H}, 6.32 ; \mathrm{N}$, 3.45. Mass Spectrum $m / e: 403\left(\mathrm{M}^{+}\right), 258,257$ (base peak), 242, 227. UV $\lambda_{\max }^{\mathrm{ttoH}} \mathrm{nm}(\varepsilon): 286(2000)$. IR $\nu_{\max }^{\mathrm{CHCl}_{3}} \mathrm{~cm}^{-1}: 1730$ (six-membered $\left.\mathrm{C}=\mathrm{O}\right), 1680$ ( $\gamma$-lactam). NMR: $6.77(2 \mathrm{H}, \mathrm{s}$, aromatic $\mathrm{H}), 4.79(1 \mathrm{H}, \mathrm{d}, J=6.5$ $\mathrm{Hz}, \mathrm{C}(10)-\mathrm{H}), 3.63(1 \mathrm{H}, \mathrm{s}, \mathrm{C}(7)-\mathrm{H}), 3.92,3.83,3.33,3.29$ (each $\left.3 \mathrm{H}, \mathrm{s}, 4 \times \mathrm{OCH}_{3}\right), 3.12\left(3 \mathrm{H}, \mathrm{s}, \mathrm{NCH}_{3}\right), 1.63$ $\left(1 \mathrm{H}, \mathrm{d}, J=10.5 \mathrm{~Hz}, \mathrm{C}(9)-\mathrm{H}_{\alpha}\right)$. Yield, $12.7 \mathrm{~g}$. TLC: Rf $0.72\left(\mathrm{Al}_{2} \mathrm{O}_{3}, \mathrm{CHCl}_{3}\right)$. Monoxime: $\mathrm{mp} 265^{\circ}$ (decomp.) (EtOH). Anal. Calcd. for $\mathrm{C}_{21} \mathrm{H}_{26} \mathrm{O}_{7} \mathrm{~N}_{2}: \mathrm{C}, 60.28 ; \mathrm{H}, 6.26 ; \mathrm{N}, 6.70$. Found: $\mathrm{C}, 60.37 ; \mathrm{H}, 6.35 ; \mathrm{N}, 6.73$. IR $v_{\max }^{\mathrm{CECl}_{3}} \mathrm{~cm}^{-1}: 1680(\gamma$-lactam).

Stephasunoline (4) (New Base)—Colorless pillars (MeOH), mp 233,$[\alpha]_{\mathrm{D}}^{20}+121.4^{\circ}\left(c=1.44, \mathrm{CHCl}_{3}\right)$. Anal. Calcd. for $\mathrm{C}_{20} \mathrm{H}_{27} \mathrm{O}_{6} \mathrm{~N}: \mathrm{C}, 63.64 ; \mathrm{H}, 7.21 ; \mathrm{N}, 3.71$. Found: $\mathrm{C}, 63.81 ; \mathrm{H}, 7.33 ; \mathrm{N}, 3.68$. Mass Spectrum $m / e: 377\left(\mathrm{M}^{+}\right), 246,245$ (base peak), 244, 230, 213. UV $\lambda_{\max }^{\mathrm{EtOH}} \mathrm{nm}(\varepsilon): 286(2000)$. IR $\nu_{\max }^{\mathrm{CHCl}_{3}} \mathrm{~cm}^{-1}: 3550(\mathrm{OH})$. NMR: 6.67 (2H, s, aromatic H), $4.88(1 \mathrm{H}, \mathrm{d}, J=6.2 \mathrm{~Hz}, \mathrm{C}(10)-\mathrm{H}), 4.25(1 \mathrm{H}, \mathrm{m}, \mathrm{C}(6)-\mathrm{H}), 4.03(1 \mathrm{H}, \mathrm{s}, \mathrm{C}(8)-\mathrm{OH})$, $3.90,3.82,3.46$ (each $\left.3 \mathrm{H}, \mathrm{s}, 3 \times \mathrm{OCH}_{3}\right), 3.62(1 \mathrm{H}, \mathrm{d}, J=3.9 \mathrm{~Hz}, \mathrm{C}(7)-\mathrm{H}), 2.82(1 \mathrm{H}, \mathrm{dd}, J=14.3,3.8 \mathrm{~Hz}, \mathrm{C}(5)-$ $\mathrm{H} \beta), 2.57\left(3 \mathrm{H}, \mathrm{s}, \mathrm{NCH}_{3}\right), 2.46\left(1 \mathrm{H}, \mathrm{dd}, J=14.3,2.4 \mathrm{~Hz}, \mathrm{C}(5)-\mathrm{H}_{\alpha}\right), 2.43(1 \mathrm{H}, \mathrm{d}, J=10.5 \mathrm{~Hz}, \mathrm{C}(6)-\mathrm{OH}), 1.54$ $\left(1 \mathrm{H}, \mathrm{d}, J=10.8 \mathrm{~Hz}, \mathrm{C}(9)-\mathrm{H}_{\alpha}\right)$. Yield, $180 \mathrm{mg}$. TLC: Rf $0.34\left(\mathrm{Al}_{2} \mathrm{O}_{3}, \mathrm{CHCl}_{3}\right)$.

Equilibration of Stephamiersine (1) and Epistephamiersine (2)_-i) A solution of 1 (100 $\mathrm{mg})$ in $1 \%$ methanolic $\mathrm{NaOH}(5 \mathrm{ml})$ was refluxed for $30 \mathrm{~min}$ and the solvent was evaporated to dryness under reduced pressure. To the residue was added water $(5 \mathrm{ml})$ and extracted with $\mathrm{CH}_{2} \mathrm{Cl}_{2}$. The $\mathrm{CH}_{2} \mathrm{Cl}_{2}$ extract, after being washed with water and dried over $\mathrm{Na}_{2} \mathrm{SO}_{4}$, was evaporated to give an amorphous solid (92 mg). TLC: Rf 0.64, $0.53\left(\mathrm{Al}_{2} \mathrm{O}_{3}, \mathrm{CHCl}_{3}\right)$. Judging from its $\mathrm{NMR}$ spectrum, this material was a mixture of 1 and 2 approximately in 1:3 ratio. The mixture was worked up via nitrate as described above to give $21 \mathrm{mg}$ of 1 and $65 \mathrm{mg}$ of 2 .

ii) A solution of $2(100 \mathrm{mg})$ in $1 \%$ methanolic $\mathrm{NaOH}(5 \mathrm{ml})$ was refluxed and worked up in the same manner as in i) to afford a colorless solid $(94 \mathrm{mg}$ ) which was judged from NMR spectrum to consists of 1 and 2 in 1: 3 ratio. The separation of the mixture was performed via nitrate to give $23 \mathrm{mg}$ of 1 and $64 \mathrm{mg}$ of 2 .

iii) Refluxing 1 or 2 in $\mathrm{MeOH}$ for $2-4 \mathrm{hr}$ resulted in complete recovery of the starting materials.

Oxidation of Stephamiersine (1) to Oxostephamiersine (3)—-To a mixture of 1 (120 mg), $\mathrm{MgSO}_{4}(120 \mathrm{mg})$, acetone $(10 \mathrm{ml})$ and water $(20 \mathrm{ml})$ was added dropwise a solution of $\mathrm{KMnO}_{4}(120 \mathrm{mg})$ in acetone $(15 \mathrm{ml})$ and water $(20 \mathrm{ml})$, and the mixture was stirred for $3 \mathrm{hr}$ at room temperature. The excess reagent was decomposed with $\mathrm{NaHSO}_{3}$ in $5 \% \mathrm{H}_{2} \mathrm{SO}_{4}$ and the solvent was evaporated under reduced pressure at room temperature. The residue was extracted with $\mathrm{CH}_{2} \mathrm{Cl}_{2}$ and the extract, after being washed successively with $2 \% \mathrm{HCl}$, $2 \% \mathrm{NaOH}$ and water and dried over $\mathrm{Na}_{2} \mathrm{SO}_{4}$, was evaporated to give a crystalline solid (58 mg) which was 
purified on silica gel column $(5 \times 0.5 \mathrm{~cm})$ with $\mathrm{CHCl}_{3}$ to afford a slightly yellow solid. Recrystallization from $\mathrm{MeOH}$ gave $38 \mathrm{mg}$ of colorless crystals, $\mathrm{mp} 290^{\circ}$. On admixture of the product with an authentic sample of 3, no depression of melting point was observed and the IR and the NMR spectra were fully identical.

Reduction of Epistephamiersine (2) to Dihydroepistephamiersine (5)_- To a solution of $2(180 \mathrm{mg})$ in $\mathrm{MeOH}$-water $(9: 1)(5 \mathrm{ml})$ was added sodium borohydride $(60 \mathrm{mg})$ and stirred for $4 \mathrm{hr}$ at room temperature, then the excess reagent was decomposed with $2 \% \mathrm{AcOH}$. The solvent was evaporated to dryness and $3 \%$ $\mathrm{NH}_{4} \mathrm{OH}$ was added to the residue. The alkaline mixture was extracted with $\mathrm{CH}_{2} \mathrm{Cl}_{2}$ and the extract was washed with water, dried over $\mathrm{Na}_{2} \mathrm{SO}_{4}$ and evaporated to afford a colorless oil $(160 \mathrm{mg})$, which was chromatographed over alumina column $(2 \times 20 \mathrm{~cm})$ with benzene to give a slightly yellow solid. Recrystallization from $\mathrm{MeOH}$ gave $130 \mathrm{mg}$ of 5 as colorless prisms, mp $63^{\circ}, 133^{\circ}$ (bimorphism). $[\alpha]_{\mathrm{D}}^{20}+75.4^{\circ}\left(c=1.84, \mathrm{CHCl}_{3}\right)$. Anal. Calcd. for $\mathrm{C}_{21} \mathrm{H}_{29} \mathrm{O}_{6} \mathrm{~N}: \mathrm{C}, 64.43 ; \mathrm{H}, 7.47 ; \mathrm{N}, 3.58$. Found: C, 64.54; H, 7.52; N, 3.54. Mass Spectrum

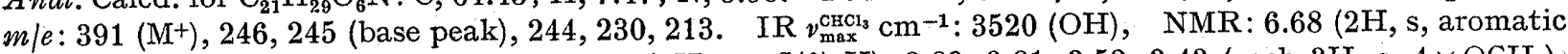
$\mathrm{H}), 4.86(1 \mathrm{H}, \mathrm{d}, J=6.5 \mathrm{~Hz}, \mathrm{C}(10)-\mathrm{H}), 4.11(1 \mathrm{H}, \mathrm{m}, \mathrm{C}(6)-\mathrm{H}), 3.89,3.81,3.52,3.43$ (each $3 \mathrm{H}, \mathrm{s}, 4 \times \mathrm{OCH}_{3}$ ), $3.61(1 \mathrm{H}, \mathrm{d}, J=3.8 \mathrm{~Hz}, \mathrm{C}(7)-\mathrm{H}), 2.53\left(3 \mathrm{H}, \mathrm{s}, \mathrm{NCH}_{3}\right), 2.06(1 \mathrm{H}, \mathrm{d}, J=9.5 \mathrm{~Hz}, \mathrm{C}(6)-\mathrm{OH}), 1.46(1 \mathrm{H}, \mathrm{d}, J=$ $\left.10.5 \mathrm{~Hz}, \mathrm{C}(9)-\mathrm{H}_{\alpha}\right)$.

Demethylation of Dihydroepistephamiersine (5) to Stephasunoline (4)_-To a solution of 5 (100 mg) in $\mathrm{MeOH}(3 \mathrm{ml})$ was added conc. $\mathrm{HCl}(0.3 \mathrm{ml})$ and allowed to stand overnight at room temperature. Romoval of the solvent under reduced pressure at room temperature gave a brownish residue. The residue was made alkaline with $3 \% \mathrm{NH}_{4} \mathrm{OH}$ and extracted with $\mathrm{CHCl}_{3}$. The $\mathrm{CHCl}_{3}$ extract, after being washed with water and dried over $\mathrm{Na}_{8} \mathrm{SO}_{4}$, was evaporated to give a slightly yellow solid which was chromatographed over silica gel column $(1 \times 12 \mathrm{~cm})$ with $\mathrm{CHCl}_{3}$. The earlier eluate gave a crystalline solid which was rechromatographed from $\mathrm{MeOH}$ to give $52 \mathrm{mg}$ of 4 as colorless pillars, $\mathrm{mp} 233^{\circ}$. This product was proved to be identical with an authentic sample of 4 by comparison of the IR and the NMR spectra and the optical rotation and mixed melting point determination.

Reduction of Stephamiersine (1) to Dihydrostephamiersine (6)-Sodium borohydride (45 mg) was added to a solution of $1(138 \mathrm{mg})$ in $\mathrm{MeOH}$-water $(9: 1)(10 \mathrm{ml})$ and the mixture was stirred at room temperature for $3 \mathrm{hr}$, then the reaction mixture was treated with the similar manner as that in the reduction of 1 to give $118 \mathrm{mg}$ of 6 as colorless prisms $(\mathrm{MeOH}), \mathrm{mp} 143^{\circ},[\alpha]_{\mathrm{D}}^{20}+102.2^{\circ}\left(c=1.14, \mathrm{CHCl}_{3}\right)$. Anal. Calcd. for $\mathrm{C}_{21} \mathrm{H}_{29} \mathrm{O}_{6} \mathrm{~N}: \mathrm{C}, 64.43 ; \mathrm{H}, 7.47 ; \mathrm{N}, 3.58$. Found: $\mathrm{C}, 64.52 ; \mathrm{H}, 7.39 ; \mathrm{N}, 3.59$. Mass Spectrum $m / e: 391\left(\mathrm{M}^{+}\right)$, 246,245 (base peak), 244, 230,213. IR $\nu_{\max }^{\mathrm{CHCl}_{s}} \mathrm{~cm}^{-1}: 3520(\mathrm{OH})$. NMR: $6.67(2 \mathrm{H}$, s, aromatic $\mathrm{H}), 4.77(1 \mathrm{H}, \mathrm{d}$, $J=6.5 \mathrm{~Hz}, \mathrm{C}(10)-\mathrm{H}), 3.91(1 \mathrm{H}, \mathrm{m}, \mathrm{C}(6)-\mathrm{H}), 3.90,3.81,3.46,3.32\left(\mathrm{each} 3 \mathrm{H}, \mathrm{s}, 4 \times \mathrm{OCH}_{3}\right), 2.50\left(3 \mathrm{H}, \mathrm{s}, \mathrm{NCH}_{3}\right)$, $1.91(1 \mathrm{H}, \mathrm{d}, J=11.5 \mathrm{~Hz}, \mathrm{C}(6)-\mathrm{OH}), 1.49\left(1 \mathrm{H}, \mathrm{d}, \mathrm{C}(9)-\mathrm{H}_{\alpha}\right)$.

Acetolysis of Stephamiersine (1) to 1,3-Diacetoxy-2,5,6-trimethoxyphenanthrene (7) - A mixture of $1(165 \mathrm{mg}), \mathrm{Ac}_{2} \mathrm{O}(3 \mathrm{ml})$ and conc. $\mathrm{HCl}(1 \mathrm{drop})$ was heated in a sealed tube at $170-180^{\circ}$ for $10 \mathrm{hr}$, and after cooling the reaction mixture was poured onto ice-water and extracted with $\mathrm{CHCl}_{3}$. The extract was washed successively with $3 \% \mathrm{HCl}, 5 \% \mathrm{NaHCO}_{3}$ and water, and dried over $\mathrm{Na}_{2} \mathrm{SO}_{4}$. Evaporation of the solvent to dryness gave a brown oil which was chromatographed over silica gel column $(1.3 \times 18 \mathrm{~cm})$ from $\mathrm{CHCl}_{3}$ and elution with the same solvent gave a slightly yellow oil. Trituration of the oil with EtOH gave a crystalline solid which was recrystallized from EtOH to give $24 \mathrm{mg}$ of 7 as slightly yellow pillars, $\mathrm{mp} 75^{\circ}$. Anal. Calcd. for $\mathrm{C}_{21} \mathrm{H}_{20} \mathrm{O}_{7}: \mathrm{C}, 65.61 ; \mathrm{H}, 5.24$. Found: $\mathrm{C}, 65.89 ; \mathrm{H}, 5.33$. Mass Spectrum $m / e: 384\left(\mathrm{M}^{+}\right)$. UV $\lambda_{\max }^{\mathrm{EtOH}} \mathrm{nm}(\varepsilon): 234,260,280,304-308$ (sh.), 345, 362. IR $v_{\max }^{\mathrm{CHCl}_{3}} \mathrm{~cm}^{-1}: 1760$ (OAc). NMR: $9.82(1 \mathrm{H}, \mathrm{s}, \mathrm{C}(4)-\mathrm{H})$, $3.97\left(3 \mathrm{H}, \mathrm{s}, \mathrm{OCH}_{3}\right), 3.92\left(6 \mathrm{H}, \mathrm{s}, 2 \times \mathrm{OCH}_{3}\right), 2.45,2.36\left(\mathrm{each} 3 \mathrm{H}, \mathrm{s}, 2 \times \mathrm{OCOCH}_{3}\right)$.

Acetolysis of Epistephamiersine (2) to 1,2,3-Triacetoxy-5,6-dimethoxyphenanthrene (8)-_-A mixture of $2(280 \mathrm{mg}), \mathrm{Ac}_{2} \mathrm{O}(4 \mathrm{ml})$ and conc. $\mathrm{HCl}(1 \mathrm{drop})$ was worked up by the same manner as that in the acetolysis of 1 to give $38 \mathrm{mg}$ of 8 as slightly yellow pillars $(\mathrm{EtOH}), \mathrm{mp} 167^{\circ}$. Anal. Calcd. for $\mathrm{C}_{22} \mathrm{H}_{20} \mathrm{O}_{8}: \mathrm{C}, 64.07 ; \mathrm{H}$, 4.89. Found: $\mathrm{C}, 65.89 ; \mathrm{H}, 5.33$. Mass Spectrum $m / e: 389\left(\mathrm{M}^{+}\right)$. UV $\lambda_{\max }^{\mathrm{EtoH}} \mathrm{nm}(\varepsilon): 258,280,306-314$ (sh.), 346, 364. IR $v_{\max }^{\mathrm{CHCl}_{3}} \mathrm{~cm}^{-1}: 1775$ (OAc). NMR: $9.47(1 \mathrm{H}, \mathrm{s}, \mathrm{C}(4)-\mathrm{H}), 3.97,3.93\left(\operatorname{each} 3 \mathrm{H}, \mathrm{s}, 2 \times \mathrm{OCH}_{3}\right)$, $2.43\left(3 \mathrm{H}, \mathrm{s}, \mathrm{OCOCH}_{3}\right), 2.33\left(6 \mathrm{H}, \mathrm{s}, 2 \times \mathrm{OCOCH}_{3}\right)$.

Acetolysis of Dihydroepistephamiersine (5) and Dihydrostephamiersine (6) to 1-Acetoxy-2,5,6-trimethoxyphenanthrene (9)-i) A mixture of $5(320 \mathrm{mg}), \mathrm{Ac}_{2} \mathrm{O}(5 \mathrm{ml})$ and conc. $\mathrm{HCl}$ (1 drop) was heated in a sealed tube at $180^{\circ}$ for $10 \mathrm{hr}$, and after cooling the reaction mixture was poured onto ice-water and extracted with $\mathrm{CHCl}_{3}$. The $\mathrm{CHCl}_{3}$ extract was washed successively with $3 \% \mathrm{HCl}, 5 \% \mathrm{NaHCO}_{3}$ and water, dried over $\mathrm{Na}_{2}-$ $\mathrm{SO}_{4}$ and evaporated to dryness. The residual oily gum was purified over silica gel column $(0.5 \times 8 \mathrm{~cm})$ with $\mathrm{CHCl}_{3}$ to afford a slightly yellow oil. Trituration of this oil with EtOH gave a crystalline solid which was recrystallized from EtOH to give $28 \mathrm{mg}$ of 9 as slightly yellow pillars, mp $139^{\circ}$. Anal. Calcd. for $\mathrm{C}_{19} \mathrm{H}_{18} \mathrm{O}_{5}$. $1 / 6 \mathrm{H}_{2} \mathrm{O}: \mathrm{C}, 69.30 ; \mathrm{H}, 5.77$. Found: $\mathrm{C}, 69.08 ; \mathrm{H}, 5.73$. Mass Spectrum m/e: $326\left(\mathrm{M}^{+}\right)$. IR $v_{\max }^{\mathrm{CHCl}_{3}} \mathrm{~cm}^{-1}: 1760$ (OAc). NMR: $9.57(1 \mathrm{H}, \mathrm{d}, J=8.3 \mathrm{~Hz}, \mathrm{C}(4)-\mathrm{H}), 4.03,3.98,3.94\left(\mathrm{each} 3 \mathrm{H}, \mathrm{s}, 3 \times \mathrm{OCH}_{3}\right), 2.46\left(3 \mathrm{H}, \mathrm{s}, \mathrm{OCOCH}_{3}\right)$. On admixture of this compound with an authentic sample of 9 no melting point depression was observed and the IR spectra $\left(\mathrm{CHCl}_{3}\right)$ of two compounds were superimposable.

ii) A mixture of $6(260 \mathrm{mg}), \mathrm{Ac}_{2} \mathrm{O}(5 \mathrm{ml})$ and conc. $\mathrm{HCl}(1$ drop) was treated with the similar manner as that in the procedure i) to give $25 \mathrm{mg}$ of 9 as slightly yellow pillars (EtOH), $\mathrm{mp} 139^{\circ}$. This compound was identical with an authentic sample of 9. 
Reduction of Oxostephamiersine (3) to Dihydrooxostephamiersine (10)—To a solution of 3 (450 $\mathrm{mg})$ in $\mathrm{MeOH}$-water $(9: 1)(80 \mathrm{ml})$ was added sodium borohydride $(150 \mathrm{mg})$ and the mixture was stirred for $4 \mathrm{hr}$ at room temperature, then the excess reagent was decomposed with $3 \%$ AcOH. The solvent was evaporated to dryness under reduced pressure, and water was added to the residue. The aqueous mixture was extracted with $\mathrm{CH}_{2} \mathrm{Cl}_{2}$ and the extract, after being washed with water and dried over $\mathrm{Na}_{2} \mathrm{SO}_{4}$, was evaporated to dryness to give a colorless oil. Trituration of this oil with $\mathrm{MeOH}$ gave a crystalline solid which was recrystallized from $\mathrm{MeOH}$-ether (4:1) to afford $380 \mathrm{mg}$ of 10 as colorless prisms, mp 236 . Anal. Calcd. for $\mathrm{C}_{21} \mathrm{H}_{27} \mathrm{O}_{7} \mathrm{~N}: \mathrm{C}_{\text {, }}$ $62.21 ; \mathrm{H}, 6.71 ; \mathrm{N}, 3.46$. Found: $\mathrm{C}, 62.09, \mathrm{H}, 6.59 ; \mathrm{N}, 3.48$. Mass Spectrum $m / e: 405\left(\mathrm{M}^{+}\right)$. IR $\nu_{\max }^{\mathrm{CHCl}_{3}} \mathrm{~cm}^{-1}$ : $3500(\mathrm{OH}), 1668(\gamma$-lactam). NMR: $6.76(2 \mathrm{H}, \mathrm{s}$, aromatic $\mathrm{H}), 4.82(1 \mathrm{H}, \mathrm{d}, J=6.5 \mathrm{~Hz}, \mathrm{C}(10)-\mathrm{H}), 3.92,3.83$, $3.40,3.36$ (each $\left.3 \mathrm{H}, \mathrm{s}, 4 \times \mathrm{OCH}_{3}\right), 3.71(1 \mathrm{H}, \mathrm{d}, J=3.2 \mathrm{~Hz}, \mathrm{C}(7)-\mathrm{H}), 2.97\left(3 \mathrm{H}, \mathrm{s}, \mathrm{NCH}_{3}\right), 2.07(1 \mathrm{H}, \mathrm{d}, J=9.4$ $\mathrm{Hz}, \mathrm{C}(6)-\mathrm{OH}), 1.62\left(1 \mathrm{H}, \mathrm{d}, J=11.0 \mathrm{~Hz}, \mathrm{C}(9)-\mathrm{H}_{\alpha}\right)$.

Compound 11 from Dihydrooxostephamiersine (10)_A mixture of $10(715 \mathrm{mg})$, AcOEt $(20 \mathrm{ml}), \mathrm{Ac}_{2} \mathrm{O}$ $(2 \mathrm{ml})$ and $70 \%$ perchloric acid $(0.5 \mathrm{ml})$ was allowed to stand for $18 \mathrm{hr}$ at room temperature. A deep violet color of the mixture turned to dark brown slowly on standing. The reaction mixture was washed with $5 \%$ $\mathrm{NaHCO}_{3}$, water and dried over $\mathrm{Na}_{2} \mathrm{SO}_{4}$. Evaporation of the solvent gave a deep brown oil which was chromatographed over alumina column $(1.5 \times 16 \mathrm{~cm})$ from benzene and elution with benzene-AcOEt $(9: 1)$ gave a slightly yellow oil $(158 \mathrm{mg})$. The oil was crystallized on trituration with hexane and recrystallization from hexane-MeOH (4:1) gave $125 \mathrm{mg}$ of 11 as colorless prisms, $\mathrm{mp} 157^{\circ}$. Anal. Calcd. for $\mathrm{C}_{20} \mathrm{H}_{21} \mathrm{O}_{5} \mathrm{~N}: \mathrm{C}, 67.59$; $\mathrm{H}, 5.96 ; \mathrm{N}, 3.94$. Found: $\mathrm{C}, 67.76 ; \mathrm{H}, 6.22 ; \mathrm{N}, 4.13$. Mass Spectrum $m / e: 355\left(\mathrm{M}^{+}\right)$. UV $\lambda_{\max }^{\mathrm{EtoH}} \mathrm{nm}(\varepsilon): 265$ (14000), $315(5000)$. IR $\nu_{\max }^{\mathrm{CHCl}_{3}} \mathrm{~cm}^{-1}: 1680$ (conj. C=O, $\gamma$-lactam), $1640(\mathrm{C}=\mathrm{C})$. NMR: 6.86 (2H, s, aromatic $\mathrm{H}), 6.80(1 \mathrm{H}, \mathrm{d}, J=9.5 \mathrm{~Hz}, \mathrm{C}(10)-\mathrm{H}), 5.96(1 \mathrm{H}, \mathrm{dd}, J=7.2,3.5 \mathrm{~Hz}, \mathrm{C}(6)-\mathrm{H}), 5.72(1 \mathrm{H}, \mathrm{d}, J=9.5 \mathrm{~Hz}, \mathrm{C}(9)-\mathrm{H})$, $3.96,3.86,3.62\left(\right.$ each $\left.3 \mathrm{H}, \mathrm{s}, 3 \times \mathrm{OCH}_{3}\right), 2.89\left(3 \mathrm{H}, \mathrm{s}, \mathrm{NCH}_{3}\right)$.

Oxidation of Epistephamiersine (2) to Oxoepistephamiersine (12)—A solution of $\mathrm{KMnO}_{4}(0.8 \mathrm{~g})$ in water $(40 \mathrm{ml})$ was added dropwise to a mixture of $2(850 \mathrm{mg}), \mathrm{MgSO}_{4}(600 \mathrm{mg})$, acetone $(30 \mathrm{ml})$ and water $(10 \mathrm{ml})$ with stirring under ice cooling, then the mixture was further stirred for $3 \mathrm{hr}$ at room temperature. The precipitated $\mathrm{MnO}_{2}$ and the excess reagent were dissolved with $\mathrm{NaHSO}_{3}$-dil. $\mathrm{H}_{2} \mathrm{SO}_{4}$ solution and the solvent was evaporated under reduced pressure at room temperature. The residue was worked up by the same way as that in the oxidation of 1 to give $185 \mathrm{mg}$ of 12 as colorless prisms (MeOH), mp 228. Anal. Calcd. for $\mathrm{C}_{21} \mathrm{H}_{25} \mathrm{O}_{7} \mathrm{~N}: \mathrm{C}, 62.52 ; \mathrm{H}, 6.25 ; \mathrm{N}, 3.47$. Found: $\mathrm{C}, 62.79 ; \mathrm{H}, 6.33 ; \mathrm{N}, 3.46$. Mass Spectrum $m / e: 403$ $\left(\mathrm{M}^{+}\right)$. IR $v_{\max }^{\mathrm{CHCl}_{3}} \mathrm{~cm}^{-1}: 1730$ (six-membered $\left.\mathrm{C}=\mathrm{O}\right), 1685$ ( $\gamma$-lactam). NMR: $6.73(2 \mathrm{H}, \mathrm{s}$, aromatic $\mathrm{H}), 4.88$ $(1 \mathrm{H}, \mathrm{d}, J=6.5 \mathrm{~Hz}, \mathrm{C}(10)-\mathrm{H}), 4.13(1 \mathrm{H}, \mathrm{s}, \mathrm{C}(7)-\mathrm{H}), 3.93,3.84,3.59,3.49\left(\right.$ each $\left.3 \mathrm{H}, \mathrm{s}, 4 \times \mathrm{OCH}_{3}\right), 3.15(3 \mathrm{H}, \mathrm{s}$, $\left.\mathrm{NCH}_{3}\right), 1.62\left(1 \mathrm{H}, \mathrm{d}, J=10.8 \mathrm{~Hz}, \mathrm{C}(9)-\mathrm{H}_{\alpha}\right)$.

Reduction of Oxoepistephamiersine (12) to Dihydrooxoepistephamiersine (13)——Sodium borohydride $(100 \mathrm{mg})$ was added to a solution of $12(298 \mathrm{mg})$ in MeOH-water $(9: 1)(20 \mathrm{ml})$, and the mixture was stirred for $4 \mathrm{hr}$ at room temperature. The reaction mixture was treated with the similar manner as that in the reduction of 3 to give $272 \mathrm{mg}$ of 13 as colorless prisms (MeOH-ether $(4: 1)$ ), mp 234 ${ }^{\circ}$. Anal. Calcd. for $\mathrm{C}_{21} \mathrm{H}_{27} \mathrm{O}_{7} \mathrm{~N}$ : $\mathrm{C}, 62.21 ; \mathrm{H}, 6.71 ; \mathrm{N}, 3.46$. Found: $\mathrm{C}, 62.11 ; \mathrm{H}, 6.78 ; \mathrm{N}, 3.53$. Mass Spectrum $m / e: 405\left(\mathrm{M}^{+}\right)$. IR $v_{\max }^{\mathrm{CHCl}_{3}}$ $\mathrm{cm}^{-1}: 3550(\mathrm{OH}), 1670(\gamma$-lactam). NMR: $6.76(2 \mathrm{H}, \mathrm{s}$, aromatic $\mathrm{H}), 4.93(1 \mathrm{H}, \mathrm{d}, J=6.5 \mathrm{~Hz}, \mathrm{C}(10)-\mathrm{H}), 4.09$ $(1 \mathrm{H}, \mathrm{m}, \mathrm{C}(6)-\mathrm{H}), 3.92,3.84,3.60,3.45\left(\right.$ each $\left.3 \mathrm{H}, \mathrm{s}, 4 \times \mathrm{OCH}_{3}\right), 3.09(1 \mathrm{H}, \mathrm{d}, J=3.9 \mathrm{~Hz}, \mathrm{C}(7)-\mathrm{H}), 3.02(3 \mathrm{H}, \mathrm{s}$, $\left.\mathrm{NCH}_{3}\right), 2.23(1 \mathrm{H}, \mathrm{d}, J=9.3 \mathrm{~Hz}, \mathrm{C}(6)-\mathrm{OH}), 1.61\left(1 \mathrm{H}, \mathrm{d}, J=10.8 \mathrm{~Hz}, \mathrm{C}(9)-\mathrm{H}_{\alpha}\right)$.

Compound 11 from Dihydrooxoepistephamiersine (13)_A solution of 13 (283 mg), AcOEt (15 ml), $\mathrm{Ac}_{2} \mathrm{O}(2 \mathrm{ml})$ and $70 \%$ perchloric acid $(0.3 \mathrm{ml})$ was allowed to stand for $18 \mathrm{hr}$ at room temperature. The mixture was washed with $5 \% \mathrm{NaHCO}_{3}$, water and dried over $\mathrm{Na}_{2} \mathrm{SO}_{4}$. Evaporation of the solvent under reduced pressure gave a brown oil which was worked up by the similar manner as that described before to afford $115 \mathrm{mg}$ of 11 as colorless prisms (hexane-MeOH $(4: 1)$ ), $\mathrm{mp} 157^{\circ}$. This product was identical with 11 derived from 10 by comparison of their IR $\left(\mathrm{CHCl}_{3}\right)$ and NMR spectra and mixed melting point determination.

Catalytic Hydrogenation of 11 to Compound 14 A solution of 11 (98 mg) in $\mathrm{MeOH}(3 \mathrm{ml})$ was hydrogenated at an atmospheric pressure over $5 \% \mathrm{Pd}-\mathrm{C}(50 \mathrm{mg})$ at room temperature. After $20 \mathrm{~min}$, the catalyst was filtered off, and the filtrate was evaporated to dryness. The residual oil (97 mg) dissolved in benzenewas chromatographed over alumina column $(2 \times 16 \mathrm{~cm})$ and elution with benzene-AcOEt $(1: 1)$ gave a colorless solid. Recrystallization from EtOH-water (4:1) gave $84 \mathrm{mg}$ of 14 as colorless prisms, $\mathrm{mp} 171^{\circ},[\alpha]_{\mathrm{D}}^{23}-143^{\circ}$ $\left(c=1.52, \mathrm{CHCl}_{3}\right)$. Anal. Calcd. for $\mathrm{C}_{20} \mathrm{H}_{23} \mathrm{O}_{5} \mathrm{~N}: \mathrm{C}, 67.21 ; \mathrm{H}, 6.49 ; \mathrm{N}, 3.92$. Found: $\mathrm{C}, 67.35 ; \mathrm{H}, 6.59 ; \mathrm{N}$, 3.95. Mass Spectrum m/e: $357\left(\mathrm{M}^{+}\right)$. IR $v_{\max }^{\mathrm{CHCl}_{3}} \mathrm{~cm}^{-1}: 1680(\gamma-\operatorname{lactam}$, conj, $\mathrm{C}=\mathrm{O}), 1640(\mathrm{C}=\mathrm{C})$. UV $\lambda_{\max }^{\mathrm{Etoy}} \mathrm{nm}$ $(\varepsilon): 276(9500)$. NMR: $6.80(2 \mathrm{H}, \mathrm{s}$, aromatic $\mathrm{H}), 5.81(1 \mathrm{H}, \mathrm{dd}, J=6.0,3.5 \mathrm{~Hz}, \mathrm{C}(6)-\mathrm{H}), 3.96,3.86,3.65$ (each $\left.3 \mathrm{H}, \mathrm{s}, 3 \times \mathrm{OCH}_{3}\right), 3.01\left(3 \mathrm{H}, \mathrm{s}, \mathrm{NCH}_{3}\right)$.

Reduction of 16-0xohasubanonine (16) to Epimeric Alcohols, 17a and 17b_-To a solution of 16 (195 $\mathrm{mg}$ ) in $\mathrm{MeOH}$-water $(9: 1)(20 \mathrm{ml})$ was added sodium borohydride $(65 \mathrm{mg})$ and the mixture was stirred for $4 \mathrm{hr}$ at room temperature. After the excess reagent was decomposed with $2 \% \mathrm{AcOH}$, the solvent was evaporated to dryness under reduced pressure and the residual oil was extracted with $\mathrm{CH}_{2} \mathrm{Cl}_{2}$. The extract was washed with water, dried over $\mathrm{Na}_{2} \mathrm{SO}_{4}$ and evaporated to give a colorless oil (186 mg) which was chromatographed. over alumina column $(1.5 \times 18 \mathrm{~cm})$ from benzene. Elution with the same solvent gave $76 \mathrm{mg}$ of $17 \mathrm{a}$ as an 
amorphous solid. IR $\nu_{\max }^{\mathrm{CHCl}_{3}} \mathrm{~cm}^{-1}: 3540(\mathrm{OH}), 1675(\gamma$-lactam), $1665(\mathrm{C}=\mathrm{C})$. NMR: 6.77 (2H, s, aromatic $\mathrm{H}), 4.28(1 \mathrm{H}, \mathrm{m}, \mathrm{C}(6)-\mathrm{H}), 3.91,3.62\left(\mathrm{each} 3 \mathrm{H}, \mathrm{s}, 2 \times \mathrm{OCH}_{3}\right), 2.93\left(3 \mathrm{H}, \mathrm{s}, \mathrm{NCH}_{3}\right)$. TLC: $R f 0.44\left(\mathrm{Al}_{2} \mathrm{O}_{3}, \mathrm{CHCl}_{3}\right)$. Further elution with benzene--EtOH $(99: 1)$ gave a colorless solid (97 $\mathrm{mg}$ ) which was recrystallized from MeOH to afford $82 \mathrm{mg}$ of $17 \mathrm{~b}$ as colorless prisms, mp 79 . Anal. Calcd. for $\mathrm{C}_{21} \mathrm{H}_{27} \mathrm{O}_{6} \mathrm{~N}: \mathrm{C}, 64.76 ; \mathrm{H}, 6.99 ; \mathrm{N}, 3.60$. Found: C, 64.64; H, 6.86; N, 3.68. Mass Spectrum m/e: $389\left(\mathrm{M}^{+}\right)$. IR $v_{\max }^{\mathrm{CrCl}_{3}} \mathrm{~cm}^{-1}: 3550,3425-3350(\mathrm{OH})$, $1675\left(\gamma\right.$-lactam), $1665(\mathrm{C}=\mathrm{C})$. NMR: $6.73(2 \mathrm{H}, \mathrm{s}$, aromatic $\mathrm{H}), 3.85\left(6 \mathrm{H}, \mathrm{s}, 2 \times \mathrm{OCH}_{3}\right), 3.83,3.47$ (each $3 \mathrm{H}, \mathrm{s}$, $\left.2 \times \mathrm{OCH}_{3}\right), 2.94\left(3 \mathrm{H}, \mathrm{s}, \mathrm{NCH}_{3}\right)$.

Compound 14 from Dihydro-16-oxohasubanonine-A (17a)__A solution of $17 \mathrm{a}(65 \mathrm{mg})$ in $\mathrm{MeOH}(3 \mathrm{ml})$ was heated with $3 \% \mathrm{HBr}(1 \mathrm{ml})$ for $10 \mathrm{~min}$ at $60^{\circ}$. The solvent was evaporated to dryness and the residue was extracted with $\mathrm{CH}_{2} \mathrm{Cl}_{2}$. The extract, after being washed with water and dried over $\mathrm{MgSO}_{4}$, was evaporated to give a colorless oil $(64 \mathrm{mg})$ which was dissolved in benzene and chromatographed over alumina column $(1.2 \times 14 \mathrm{~cm})$. Elution with benzene-AcOEt $(1: 1)$ gave a colorless solid which was recrystallized from EtOH-water $(4: 1)$ to afford $54 \mathrm{mg}$ of 14 as colorless prisms, $\mathrm{mp} 171^{\circ},[\alpha]_{\mathrm{D}}^{25}-141^{\circ}\left(c=1.26, \mathrm{CHCl}_{3}\right) . \mathrm{On}^{\circ}$ admixture of this compound with 14 derived from 11 no melting point depression was observed and the IR spectra $\left(\mathrm{CHCl}_{3}\right)$ were superimposable.

Compound 14 from Dihydro-16-oxohasubanonine $(\mathbf{1 7 b})$ - To a solution of $17 \mathrm{~b}(42 \mathrm{mg})$ in acetone $(3 \mathrm{ml})$ was added $3 \% \mathrm{HBr}(0.5 \mathrm{ml})$ and the mixture was heated for $5 \mathrm{~min}$ at $60^{\circ}$. After the solvent was evaporated, the residue was extracted with $\mathrm{CHCl}_{3}$. The $\mathrm{CHCl}_{3}$ extract was carried out by the similar manner as the described above to give $34 \mathrm{mg}$ of 14 as colorless prisms, $\mathrm{mp} 171^{\circ}$. This product was identical with 14 derived from $17 \mathrm{a}$ in every respect.

Acknowledgment The authors are grateful to Emeritus Professor M. Tomita, Kyoto University, for his continuing interest and hearty encouragement. Sincere thanks are also due to Professor Y. Inubushi, Kyoto University, for his valuable guidances. The authors are also indebted to Professor T. Shingu, Kobe Gakuin University, and Dr. K. Fujitani, Kyoto College of Pharmacy, for their discussions and helpful suggestions. Grateful acknowledgment is made to Professor S.M. Kupchan, University of Virginia, Professor D.H.R. Barton, Imperial College, and Dr. A. Wiechers, University of Pretoria, for sending the copies of their spectral charts. The authors indebted to Professor K. Itoh, Meijo University, and Dr. C.W. Thornber, Imperial Chemical Industries Ltd. (England), for their useful informations and to Dr. K. Kitamura, Kyoto College of Pharmacy, and Mr. Y. Ikebe, Naka Work, Hitachi Co., Ltd., for NMR measurements and to Mr. Y. Kato, Naka. Work, Hitachi Co., Ltd., and Mr. M. Tajimi, Japan Electron Optics Laboratory Co., Ltd., for mass spectral measurements and to Mr. T. Nishiyori, Daiichi College of Pharmaceutical Sciences, for elemental analyses. Thanks are also due to Mrs. K. Sunagawa and Mr. S. Satoh, Daiichi College of Pharmaceutical Sciences, for their technical assistance. The plant material was kindly supplied by Mr. K. Yadori, Bohnotsu-cho, Kagoshima-ken. The methanolic extract was made at Suzuka Work, Dainippon Pharmaceutical Co., Ltd., to which the authors' thanks are due. 